\title{
Americium-Curium Stabilization - 5" Cylindrical Induction Melter System Design Basis
}

by

D. C. Witt

Westinghouse Savannah River Company

Savannah River Site

Aiken, South Carolina 29808

DOE Contract No. DE-AC09-96SR18500

This paper was prepared in connection with work done under the above contract number with the U.S.

Department of Energy. By acceptance of this paper, the publisher and/or recipient acknowledges the U.S.

Government's right to retain a nonexclusive, royalty-free license in and to any copyright covering this paper, along with the right to reproduce and to authorize others to reproduce all or part of the copyrighted paper. 


\section{DISCLAIMER}

Portions of this document may be illegible in electronic image products. Images are produced from the best available original document. 


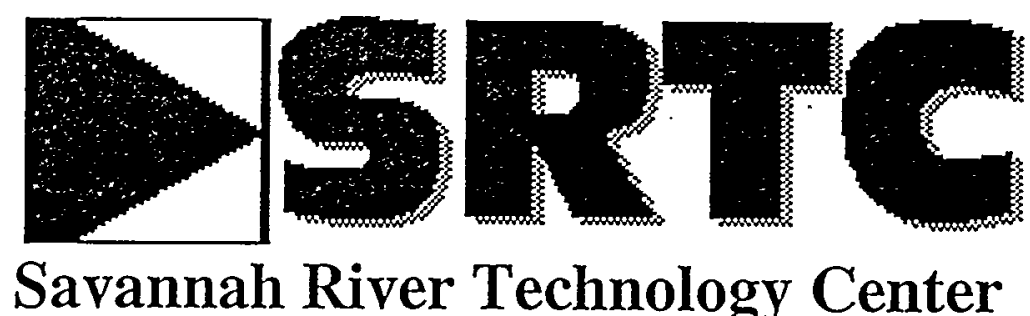

SRT-AMC-99-0001

Revision 0

\section{Americium-Curium Stabilization - 5" Cylindrical Induction Melter System Design Basis (U)}

January 15, 1999 


\section{DISCLAIMER}

This report was prepared as an account of work sponsored by an agency of the United States Government. Neither the United States Government nor any agency thereof, nor any of their employees, makes any warranty, express or implied, or assumes any legal liability or responsibility for the accuracy, completeness, or usefulness of any information, apparatus, product, or process disclosed, or represents that its use would not infringe privately owned rights. Reference herein to any specific commercial product, process, or service by trade name, trademark, manufacturer, or otherwise does not necessarily constitute or imply its endorsement, recommendation, or favoring by the United States Government or any agency thereof. The views and opinions of authors expressed herein do not necessarily state or reflect those of the United States Government or any agency thereof.

This report has been reproduced directly from the best available copy.

Available to DOE and DOE contractors from the Office of Scientific and Technical Information, P.O. Box 62, Oak Ridge, TN 37831; prices available from (615) 576-8401.

Available to the public from the National Technical Information Service, U.S. Department of Commerce; 5285 Port Royal Road, Springfield, VA 22161. 


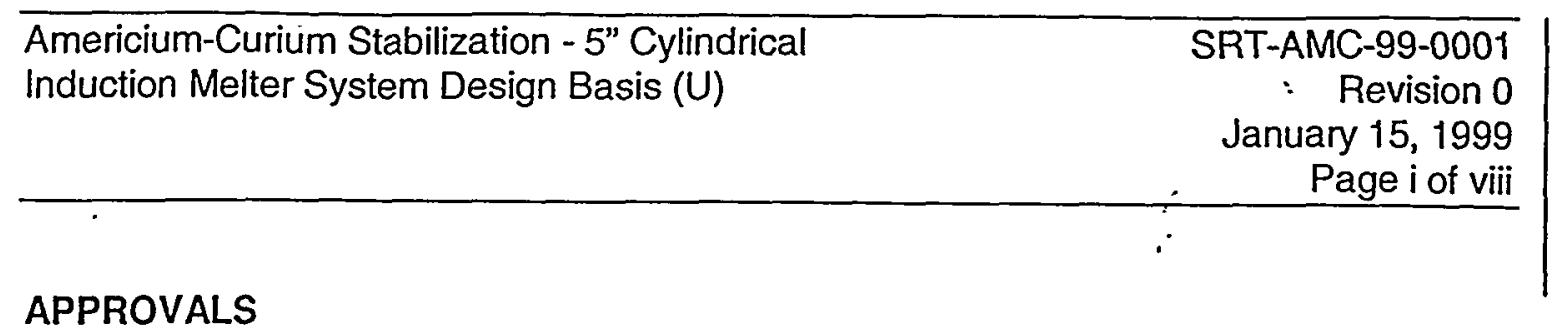

APPROVALS

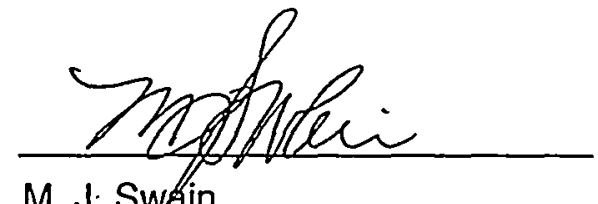

SRTC Am-Cm Project Manager

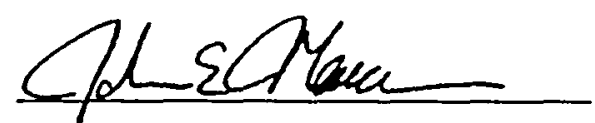

J. E. Nara

SRTC Am-Cm Technical Program Manager

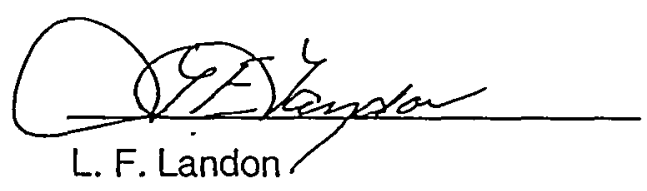

Manager, SRTC/ITS Actinide Glass Processing

TECHNICAL REVIEW

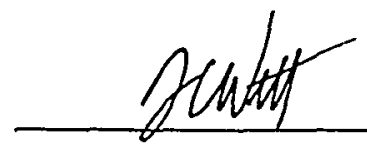

D. C. Witt

Principal Investigator, Am-Cm Pilot Test Facilities

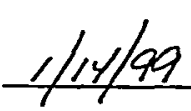

Date

$1 / 14 / 99$

Date

$1 / 141 / 99$

Date

$\frac{1 / 14 / 99}{\text { Date }}$ 
Americium-Curium Stabilization - 5" Cylindrical Induction Melter System Design Basis (U)
SRT-AMC-99-0001

- Revision 0

January 15, 1999

Page ii of viii

This Page Intentionally Left Blank 
Americium-Curium Stabilization - 5" Cylindrical

Induction Melter System Design Basis (U)

SRT-AMC-99-0001

: Revision 0

January 15, 1999

Page iii of viii

\section{TABLE OF CONTENTS}

Approvals

Table of Contents

List of Figures

vii

List of Tables

vii

Introduction

Material Balance

Feed Description

3

General

3

Control of Composition of Feed Batched to Precipitator Batch Tank

3

Glass Former

Composition

$\cdot 6$

Particle Size

Product Description

Nominal Composition

Product Density

Product Viscosity

Acceptance Criteria

Processing Criteria

Product Performance Criteria

6

7

7

9

9

9

$\begin{array}{lr}\text { Flammability Control } & 10\end{array}$

$\begin{array}{ll}\text { Canister } & 10\end{array}$

General $\quad$. 10

Design Bases $\quad \cdot 11$

$\begin{array}{ll}\text { Canister Scale } & 11\end{array}$

General •

Design Bases 11 
Americium-Curium Stabilizátion - 5" Cylindrical

SRT-AMC-99-0001

Induction Melter System Design Basis (U)

\section{TABLE OF CONTENTS (cont.)}

$\begin{array}{ll}\text { Melter Feed Prep } & 11\end{array}$

General 11

Feed Tank 12

General 12

Compositional Control 12

Design Bases 12

Minimum Services 13

Minimum Real-time Monitoring Parameters 13

Recommended Alarms/Interlocks 13

Precipitator Batch Tank 13

General 13

Design Bases $\quad \cdot \quad 13$

Minimum Services 14

Minimum Real-time Monitoring Parameters 14

Recommended Alarms/Interiocks $\quad 14$

Precipitator $\quad-15$

General $\quad 15$

Cycle 15

Process Operating Parameters 16

Design Bases 16

Minimum Services. 18

Minimum Real-time Monitoring Parameters $\quad \because 18$

$\begin{array}{ll}\text { Recommended Alarms/Interlocks } & 18\end{array}$

Spent Wash Tank 20

General 20

Design Bases $\quad .21$

Minimum Services $\quad 21$

Minimum Real-time Monitoring Parameters $\quad 21$

Recommended Alarms/Interlocks $\quad 21$

Vitrification $\quad .22$

$\begin{array}{ll}\text { General } & 22\end{array}$

CIM 5 Batch Vitrification Cycle 23

Melter Vessel 26

Design Bases $\quad 26$

Minimum Real-time Monitoring Parameters $\quad 27$

Recommended Alarms/lnterlocks $\quad 27$ 


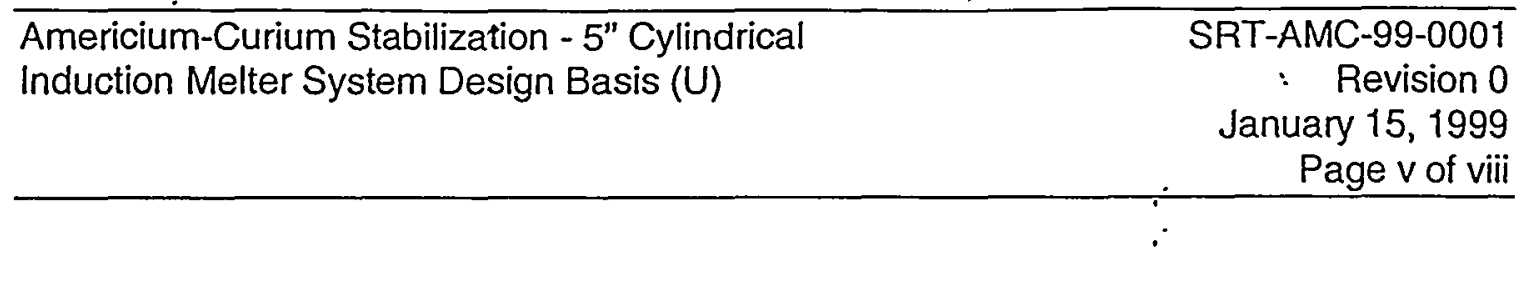

TABLE OF CONTENTS (cont.)

$\begin{array}{ll}\text { Heating System } & 27\end{array}$

Melter Vessel 27

Melter Vessel \& Vessel Bottom (Cone) Power Supplies 28

Design Bases 28

Services 28

Minimum Real-time Monitoring Parameters 29

Recommended Alarms/Interlocks $\quad 29$

Power Ramp Limitation . . 29

Cooling Water Heat Exchanger Unit 29

General 29

Design Bases $\quad \cdot 30$

Services $\quad 30$

Recommended Alarms/Interlocks $\quad 30$

$\begin{array}{ll}\text { Glass Pouring } & 35\end{array}$

General 35 .

Cycle 36

Pouring Sequence 36

Drain Tube Power Ramp Sequence 37

Drain Tube $\quad 37$

Design Bases , 37

Minimum Real-time Monitoring Parameters $\quad 39$

Services $\quad 40$

Recommended Alarms/Interlocks ${ }^{\cdot} 40$

Heating System $\quad 41$

General 41

Design Bases $\quad 41$

Services 41

Minimum Real-time Monitoring Parameters $\quad \cdot \quad 41$

Recommended Alarms/interlocks $\quad 42$

Power Ramp Limitation $\quad 43$

Cooling Water Heat Exchanger Unit 43 |

Melter Off-Gas Treatment 43

General 43

Melter Ventilation Exhaust Hood 43

Design Bases 43 
TABLE OF CONTENTS (cont.)

Moisture Separator 45

- Design Bases

Dilution Air

Design Bases

High-Efficiency Particulate Air Filter 46 Design Bases

Exhauster 46

Design Bases

Process Control/Data Acquisition System $\quad \therefore \quad 46$

$\begin{array}{ll}\text { General Requirements } & 46\end{array}$

$\begin{array}{ll}\text { Induction Power Controls } & 47\end{array}$

$\begin{array}{ll}\text { Power Station Status } & -47\end{array}$

Melter Controls $\quad 47$

Cone Power Control 48

Pour Tip Power Control 48

Recommended Alarms/Interlocks $\quad 48$

Data Collection 48

Process Operations Logging $\quad 48$

Glass Pouring Controls $\quad 48$

References $\quad 49$

Laboratory Notebooks $\quad 50$

Attachments

Attachment 1 - Schematic Diagram of 5-Inch 
Americium-Curium Stabilization - 5" Cylindrical

Induction Melter System Design Basis (U)

SRT-AMC-99-0001

: Revision 0

January 15, 1999

Page vii of viii

\section{LIST OF FIGURES}

Figure IX-1

Figure IX-2

Figure $X-1$

Figure $X-2$

Figure $X-3$

Figure $X-4$

Figure $\mathrm{XI}-1$

Figure $X 1-2$

Figure $X \mathrm{I}-3$

Figure $\mathrm{XI}-4$
Precipitator Tank for 5-Inch CIM

19

Particle Size Distribution for Washed Oxalate Solids 20

5-Inch CIM Vessel

3-Inch CIM Outside Surface Temperatures

31

5-Inch CIM Temperature Measurement Locations . 33

5-Inch CIM Coil Dimensions $\quad 34$

Drain Tube Power Ramp Plot 38

Drain Tube Configuration $\quad 39$

Graphic Representation of Spacing Relationship $\quad 40$

Of Drain Tube to Insulation Tube and to Coil

Drain Tube Induction Coil Dimensions

\section{LIST OF.TABLES}

Table III-1

Table III-2

Tank 17.1 Composition

4

Tank 17.3E Post-Pretreatment Composition 5

Table IV-1

Compositional Tolerance for the 25SrABS Frit

6

Table V-1

Actinide-Bearing Feed Materials, 25SrABS Frit

$\cdot 8$

Table V-2

Composition and Target Glass Composition

("actual" and surrogate) on an Oxide (wt\%) Basis

Viscosity of AmCm-1a Surrogate Glass as a

Function of Temperature 
Americium-Curium Stabilizátion - 5" Cylindrical Induction Melter System Design Basis (U)
SRT-AMC-99-0001

: Revision 0

January 15, 1999

Page viii of viii

This Page Intentionally Left Blank 
Americium-Curium Stabilization - 5" Cylindrical

Induction Melter System Design Basis (U)
SRT-AMC-99-0001

: Revision 0

January 15, 1999

Page 1 of 52

\section{INTRODUCTION}

Approximately 11,000 liters (3,600 gallons) of solution containing isotopes of Am and $\mathrm{Cm}$ are currently stored in F-Canyon Tank 17.1. These isotopes were recovered during plutonium-242 production campaigns in the mid-and late-1970's. The continued storage of these isotopes was identified as an item of primary concern in the Defense Nuclear Facility Safety Board's (DNFSB) Recommendation 94-1 [Ref. 1]. Currently, there are no existing SRS facilities that can be used to stabilize this material for safe interim storage and transportation to the heavy isotopes program at the Oak Ridge National Laboratory (ORNL). An analysis of several alternatives resulted in the recommendation to stabilize the Am-Cm solution in a high-lanthanide glass [Ref. 2,3]. The Multi-Purpose Processing Facility (MPPF) in the F-Canyon will be used for the vitrification process. Pretreatment operations will be performed in existing canyon vessels to separate actinides and lanthanides from other impurities (primarily iron, aluminum, and sodium) prior to the vitrification operation.

Experimental work for the project began in 1995 by the Savannah River Technology Center (SRTC). Surrogate (non-radioactive) feed solutions were used. Initially, platinum-bushing melters were investigated. After several years of development work with various bushing melter designs, it was determined that the technical risks associated with a bushing melter were unacceptable, and therefore, work began on development of a platinum cylindrical induction melter (CIM). The CIM allowed for more precise temperature control throughout the melter, is more structurally sound at the high temperatures required for vitrification of this particular feed, and is better suited to the MPPF environment. The other major process modification was the move to a batch process. The proposed baseline flowsheet involves precipitating the actinide materials with oxalic acid and washing the precipitate to lower the nitric acid concentration. The subsequent oxalate precipitate is then mixed with glass formers. The resultant mixture is then dried and heated to approximately $1450^{\circ} \mathrm{C}$ to produce a molten glass product. The glass is then poured through a drain tube into a stainless steel cylinder. A more detailed summary of this process development can be found in the Am-Cm Stabilization Development Program Plan [Ref. 4]. Details of the process are given in the various sections of this document, and Attachment 1 gives an overall flowsheet of the process.

Following testing on the 3-inch Cylindrical Induction Melter in September 1998, a document was prepared to provide preliminary design basis information for the CIM system to the Design Team [Ref. 5]. The original document included information for the 3-inch CIM system, as well as information for the 5-inch system that was being installed. Following installation of the 5-inch CIM system, a series of runs were completed to characterize the system and demonstrate the batch vitrification flowsheet. These tests culminated with the completion of four Integrated Demonstration Runs in the 5-inch CIM in December 1998 [Ref. 6]. This document provides the design bases information for the batch vitrification process in the 5-inch CIM system. 
Americium-Curium Stabilization - 5" Cylindrical

Induction Melter System Design Basis (U)
SRT-AMC-99-0001

: Revision 0

January 15, 1999

Page 2 of 52

There are several limitations with regards to the design bases that should be noted:

- Several operational bases are preliminary in that development activities are still in progress and will continue throughout FY1999. Preliminary information provided is that necessary to initiate the design process. Potential changes to these operational bases resulting from additional Pilot Facility testing will not impact fundamental design bases without formal design change control.

- It is assumed that the vitrification cycle is accomplished by controlling power to the induction coils (i.e. no temperature sensors monitoring the contents of the melter, the melter vessel or the drain tube).

- Power system specifications, heating stations, induction coil configurations, etc. are as specified by Ameritherm (the vendor of the.Pilot Scale Systems) for the

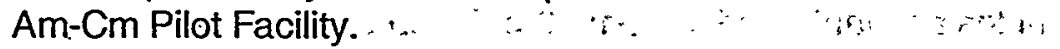

- The MPPF Design Authority will specify the final configuration for transfers between Tank 17.3E and the Feed Tank, between the Feed Tank and the Batch Tank and between the Spent Wash Tank and the Precipitator.

- Criteria for determining the capacity of process vessels lies with the Design Authority and Design.

- The Preliminary Design Basis Document does not address canister welding.

- The Preliminary Design Basis Document does not addreśs glass sampling.

- The Preliminary Design Basis Document dóes nót addrèss techniques or criteria for analytically determining the composition of the $\mathrm{Am} / \mathrm{Cm}$ contents of a canister.

- The final frit requirement will be based on Tank 17.3E analyses, specific gravity of Feed Tank contents, and precipitator batch volume. Sampling of feed - beyond Tank 17.3E is not required as part of the baseline process. :

\section{MATERIAL BALANCE}

The Preliminary Design Basis Document [Ref. 5] provided material balance calculations for the Americium-Curium pretreatment and vitrification prócésses. During the 5-inch CIM Integrated Demonstration Runs; a total lanthanide loading of $\sim 60 \%$ was used. This translates to a Tank $17.3 \mathrm{E}$ loading of $\sim 47 \%$ as opposed to the material balance bases of $28 \%$. Additional work is underway to determine the optimal and bounding lanthanide loading for the batch flowsheet. Upon completion of this work, the material balance will be updated. As a result, the material balance is not presented in this document. Additionally; as discuissed above, any changes resulting from a change in the material balance will be'accommodated such that the design effort is not impacted. 
Americium-Curium Stabilization - 5" Cylindrical

Induction Melter System Design Basis (U)
SRT-AMC-99-0001

: Revision 0

January 15, 1999

Page 3 of 52

\section{FEED DESCRIPTION}

\section{General}

Tables III-1 and III-2 give the composition of Tanks 17.1 and 17.3 (post pre- treatment). The tables include the following information and are based on the material balance that was updated in September 1998 to reflect the February 1998 analysis of Tank 17.1 [Ref. 5].

- Nominal Cation Content in $\mathrm{mg} / \mathrm{L}$

- Nominal Anion Content in $\mathrm{mg} / \mathrm{L}$

- Nominal HNO3 Concentration, M

- Specific Gravity

- Nominal Total Solids Concentration on an Oxide basis

- Radionuclide Concéntration Including Watts/Liter per Radionuclide and Total Heat Content

Note: Tank 17.1 values based on 15,000 liter feed volume, Tank 17.3 based on 1166 liter feed volume.

\section{Control of Composition of Feed Batched to Precipitator Batch Tank}

Once the Am/Cm feed has been pre-treated in the canyon and accumulated in the 17.3E Evaporator, it will be the responsibility of Operations to sample and compositionally characterize the feed. Of paramount importance is that Operations maintain a set composition, since it is not practical to compositionally characterize each batch of feed batched to the Precipitator. This can be best accomplished by establishing a relationship between the specific gravity of the contents of $17.3 \mathrm{E}$ and the total solids contents on an oxide basis. By assuring that the specific gravity of the contents of 17.3E remain within an established tolerance of specific gravity, down stream process-operating parameters can be established and held to as constants. 
Americium-Curium Stabilization - 5" Cylindrical

SRT-AMC-99-0001

Induction Melter System Design Basis (U)

: Revision 0

January 15, 1999

Page 4 of 52

TABLE III-1. Tank 17.1 Composition

\begin{tabular}{|c|c|c|c|c|c|}
\hline Cation & $\begin{array}{l}\text { Cations } \\
(\mathrm{mg} / \mathrm{l})\end{array}$ & Oxide & $\begin{array}{l}\text { Oxides } \\
\text { (mg/l) }\end{array}$ & Anion & $\begin{array}{l}\text { Anions } \\
(\mathrm{mg} / \mathrm{l})\end{array}$ \\
\hline \multicolumn{6}{|l|}{ Lanthanides } \\
\hline $\mathrm{La}$ & 984.56 & $\mathrm{La}_{2} \mathrm{O}_{3}$ & 1154.69 & $\mathrm{NO}_{3}$ & 16662.22 \\
\hline $\mathrm{Ce}$ & 773.78 & $\mathrm{Ce}_{2} \mathrm{O}_{3}$ & 906.33 & $\mathrm{NO}_{2}$ & 676.79 \\
\hline $\mathrm{Pr}$ & 661.17 & $\mathrm{Pr}_{2} \mathrm{O}_{3}$ & 773.77 & $\mathrm{C}_{2} \mathrm{O}_{4}$ & 1147.59 \\
\hline $\mathrm{Nd}$ & 1898.99 & $\mathrm{Nd}_{2} \mathrm{O}_{3}$ & 2214.22 & $\mathrm{SO}_{4}$ & 9566.49 \\
\hline $\mathrm{Sm}$ & 450.12 & $\mathrm{Sm}_{2} \mathrm{O}_{3}$ & 521.91 & $F$ & 208.02 \\
\hline $\mathrm{Eu}$ & 91.45 & $\mathrm{Eu}_{2} \mathrm{O}_{3}$ & 105.88 & $\mathrm{PO}_{4}$ & 1197.08 \\
\hline Gd & 232.12 & $\mathrm{Gd}_{2} \mathrm{O}_{3}$ & 267.54 & $\mathrm{Cl}$ & 970.44 \\
\hline $\mathrm{Tb}$ & 30.27 & $\mathrm{~Tb}_{2} \mathrm{O}_{3}$ & 34.84 & & \\
\hline Dy & 30.26 & $\mathrm{Dy}_{2} \mathrm{O}_{3}$ & 34.74 & $\therefore$ & \\
\hline Ho & 30.27 & $\mathrm{Ho}_{2} \mathrm{O}_{3}$ & 34.67 & & \\
\hline $\mathrm{Er}$ & 30.27 & $\mathrm{Er}_{2} \mathrm{O}_{3}$ & 34.61 & & \\
\hline $\mathrm{Tm}$ & 40.40 & $\mathrm{Tm}_{2} \mathrm{O}_{3}$ & 46.46 & & \\
\hline $\mathrm{Yb}$ & 30.27 & $\mathrm{Yb}_{2} \mathrm{O}_{3}$ & 34.46 & & \\
\hline $\mathrm{Lu}$ & 30.26 & $\mathrm{Lu}_{2} \mathrm{O}_{3}$ & 34.41 & & \\
\hline \multicolumn{6}{|l|}{ Actinides } \\
\hline $\mathrm{Am}$ & 594.64 & $\mathrm{Am}_{2} \mathrm{O}_{3}$ & 653.39 & & \\
\hline $\mathrm{Cm}$ & 146.99 & $\mathrm{Cm}_{2} \mathrm{O}_{3}$ & 161.27 & & $\cdot$ \\
\hline $\mathrm{Np}$ & 1.73 & $\mathrm{~Np}_{2} \mathrm{O}_{5}$ & 1.90 & & \\
\hline $\mathrm{Pu}$ & 158.73 & $\mathrm{PuO}_{2}$ & 174.35 & & \\
\hline $\mathrm{U}$ & 610.08 & $\mathrm{UO}_{3}$ & 733.07 & & \\
\hline Cs & 3.56 & $\mathrm{Cs}_{2} \mathrm{O}$ & 3.77 & & \\
\hline \multicolumn{6}{|l|}{ Metals } \\
\hline $\mathrm{Al}$ & 1094.16 & $\mathrm{Al}_{2} \mathrm{O}_{3}$ & 2067.41 & & 5 \\
\hline $\mathrm{Ca}$ & 66.61 & $\mathrm{CaO}$ & 93.20 & & $\cdots$ \\
\hline $\mathrm{Cr}$ & 393.88 & $\mathrm{Cr}_{2} \mathrm{O}_{3}$ & 575.70 & & \\
\hline $\mathrm{Fe}$ & 4853.59 & $\mathrm{Fe}_{2} \mathrm{O}_{3}$ & 6939.17 & $\ddot{\sim}$ & \\
\hline $\mathrm{K}$ & 217.00 & $\mathrm{~K}_{2} \mathrm{O}$ & 261.40 & & \\
\hline $\mathrm{Mn}$ & 242.72 & $\mathrm{MnO}$ & 313.40 & & \\
\hline $\mathrm{Na}$ & 549.37 & $\mathrm{Na}_{2} \mathrm{O}$ & 740.55 & & \\
\hline $\mathrm{Ni}$ & 288.41 & $\mathrm{NiO}$ & 367.03 & & \\
\hline $\mathrm{Zn}$ & 21.20 & $\mathrm{ZnO}$ & 26.39 & & \\
\hline $\mathrm{Zr}$ & 4.07 & $\mathrm{ZrO}_{2}$ & 5.49 & & \\
\hline Radionuclide & $\begin{array}{l}\text { Watts per gm } \\
\text { Radionuclide }\end{array}$ & $\begin{array}{l}\text { Total Watts } \\
\text { per Liter per } \\
\text { Radionuclide }\end{array}$ & $\begin{array}{c}\text { Total Solids } \\
\text { Oxide Basis } \\
(\mathrm{g} / \mathrm{l})\end{array}$ & $\begin{array}{c}\text { Nominal } \\
\text { HNO3 Conc. } \\
\text { (M) }\end{array}$ & $\begin{array}{l}\text { Specific } \\
\text { Gravity } \\
\left(\mathrm{g} / \mathrm{cm}^{3}\right)\end{array}$ \\
\hline$U$ & $3.73 E-07$ & $2.2756 \mathrm{E}-07$ & 19.32 & 5.7 & 1.20 \\
\hline $\mathrm{Pu}$ & 0.0396 & 0.0063 & & & \\
\hline Am & 0.0105 & 0.0062 & & & \\
\hline \multirow[t]{3}{*}{$\mathrm{Cm}$} & 2.7200 & 0.3998 & & & \\
\hline & & & & & \\
\hline & Total W/iter & 0.412 & & & \\
\hline
\end{tabular}


Americium-Curium Stabilizafion - 5" Cylindrical

Induction Melter System Design Basis (U)

SRT-AMC-99-0001

: Revision 0

January 15, 1999

Page 5 of 52

TABLE III-2. Tank 17.3 Post Pretreatment Composition

\begin{tabular}{|c|c|c|c|c|c|}
\hline Cation & $\begin{array}{c}\text { Cations } \\
(\mathrm{mg} / \mathrm{l})\end{array}$ & Oxide & $\begin{array}{c}\text { Oxides } \\
\text { (mg/l) }\end{array}$ & Anion & $\begin{array}{c}\text { Anions } \\
\text { (mg/l) }\end{array}$ \\
\hline \multicolumn{6}{|l|}{ Lanthanides } \\
\hline La & 12577.34 & $\mathrm{La}_{2} \mathrm{O}_{3}$ & 14750.71 & $\mathrm{NO}_{3}$ & 111100 \\
\hline $\mathrm{Ce}$ & 9911.79 & $\mathrm{Ce}_{2} \mathrm{O}_{3}$ & 11609.69 & $\mathrm{NO}_{2}$ & 157.36 \\
\hline $\mathrm{Pr}$ & 8490.90 & $\mathrm{Pr}_{2} \mathrm{O}_{3}$ & 9936.90 & $\mathrm{C}_{2} \mathrm{O}_{4}$ & 267.05 \\
\hline $\mathrm{Nd}$ & 24409.96 & $\mathrm{Nd}_{2} \mathrm{O}_{3}$ & 28462.01 & $\mathrm{SO}_{4}$ & 2219.80 \\
\hline $\mathrm{Sm}$ & 5770.64 & $\mathrm{Sm}_{2} \mathrm{O}_{3}$ & 6691.06 & $\mathrm{~F}$ & 48.32 \\
\hline $\mathrm{Eu}$ & 1173.51 & $\mathrm{Eu}_{2} \mathrm{O}_{3}$ & 1358.69 & $\mathrm{PO}_{4}$ & 278.33 \\
\hline $\mathrm{Gd}$ & 2982.23 & $\mathrm{Gd}_{2} \mathrm{O}_{3}$ & 3437.32 & $\mathrm{Cl}$ & 225.56 \\
\hline $\mathrm{Tb}$ & 377.80 & $\mathrm{~Tb}_{2} \mathrm{O}_{3}$ & 434.85 & & \\
\hline Dy & 377.67 & $\mathrm{Dy}_{2} \mathrm{O}_{3}$ & 433.45 & & \\
\hline Ho & 377.85 & $\mathrm{Ho}_{2} \mathrm{O}_{3}$ & 432.82 & & \\
\hline $\mathrm{Er}$ & 377.82 & $\mathrm{Er}_{2} \mathrm{O}_{3}$ & 432.00 & & \\
\hline $\mathrm{Tm}$ & 507.83 & $\mathrm{Tm}_{2} \mathrm{O}_{3}$ & $\ldots \quad 579.99$ & & \\
\hline$Y b$ & 377.35 & $\mathrm{Yb}_{2} \mathrm{O}_{3}$ & 429.69 & & \\
\hline $\mathrm{Lu}$ & 377.10 & $\mathrm{Lu}_{2} \mathrm{O}_{3}$ & 428.80 & & \\
\hline \multicolumn{6}{|l|}{ Actinides } \\
\hline $\mathrm{Am}$ & 7605.68 & $\mathrm{Am}_{2} \mathrm{O}_{3}$ & 8357.12 & & \\
\hline $\mathrm{Cm}$ & 1872.82 & $\mathrm{Cm}_{2} \mathrm{O}_{3}$ & 2054.85 & & \\
\hline $\mathrm{Np}$ & 0.40 & $\mathrm{~Np}_{2} \mathrm{O}_{5}$ & 0.44 & & \\
\hline $\mathrm{Pu}$ & 89.84 & $\mathrm{PuO}_{2}$ & 98.68 & & \\
\hline$U$ & 141.83 & $\mathrm{UO}_{3}$ & 170.42 & & \\
\hline Cs & 0.82 & $\mathrm{Cs}_{2} \mathrm{O}$ & 0.87 & & \\
\hline \multicolumn{6}{|l|}{ Metals } \\
\hline $\mathrm{Al}$ & 254.19 & $\mathrm{Al}_{2} \mathrm{O}_{3}$ & 480.29 & & \\
\hline $\mathrm{Ca}$ & 15.49 & $\mathrm{CaO}$ & 21.67 & & \\
\hline $\mathrm{Cr}$ & 91.53 & $\mathrm{Cr}_{2} \mathrm{O}_{3}$ & 133.79 & & \\
\hline $\mathrm{Fe}$ & 1127.00 & $\mathrm{Fe}_{2} \mathrm{O}_{3}$ & 1611.27 & & \\
\hline $\mathrm{K}$ & 50.28 & $\mathrm{~K}_{2} \mathrm{O}$ & 60.56 & & \\
\hline $\mathrm{Mn}$ & 6152.48 & $\mathrm{MnO}$ & 7944.08 & & \\
\hline $\mathrm{Na}$ & 127.65 & $\mathrm{Na}_{2} \mathrm{O}$ & 172.08 & & \\
\hline $\mathrm{Ni}$ & 67.15 & $\mathrm{NiO}$ & 85.46 & & $\therefore$ \\
\hline $\mathrm{Zn}$ & 4.94 & $\mathrm{ZnO}$ & 6.14 & & \\
\hline $\mathrm{Zr}$ & 0.94 & $\mathrm{ZrO}_{2}$ & 1.27 & & \\
\hline Radionuclide & $\begin{array}{l}\text { Watts per gm } \\
\text { Radionuclide }\end{array}$ & $\begin{array}{l}\text { Total Watts } \\
\text { per Liter per } \\
\text { Radionuclide }\end{array}$ & $\begin{array}{c}\text { Total Solids } \\
\text { Oxide Basis } \\
(\mathrm{g} / \mathrm{l})\end{array}$ & $\begin{array}{c}\text { Nominal } \\
\text { HNO3 Conc. } \\
(\mathrm{M}) \\
\end{array}$ & $\begin{array}{l}\text { Specific } \\
\text { Gravity } \\
\left(\mathrm{g} / \mathrm{cm}^{3}\right)\end{array}$ \\
\hline$U$ & 3.73E-07 & 5.2902E-08 & 100.62 & 1.0 & 1.20 \\
\hline $\mathrm{Pu}$ & 0.0396 & 0.0036 & & & \\
\hline $\mathrm{Am}$ & 0.0105 & 0.0799 & & & \\
\hline $\mathrm{Cm}$ & 2.7200 & 5.0941 & & & \\
\hline & Total W/iter & 5.18 & & & \\
\hline
\end{tabular}




\section{GLASS FORMER}

\section{Composition}

The nominal 25SrABS frit composition (see Table IV-1) was selected based on a balance between the feed loading, melting characteristics of the frit, and interactions between the frit and the oxalate precipitate. Although the specifications for size and size distribution are not defined at this time, the $25 \mathrm{SrABS}$ frit was obtained from a vendor to súpport testing in the Drain Tube Test Stand (DTTS) and the Cylindrical Induction-Heated Melter (CIM) and will be manufactured to the compositional specifications for operations (FY99) testing. The compositional specifications submitted to the vendor are shown in Table IV-1.

Table IV-1. Compositional Tolerance for the 25SrABS Frit

Component

$\mathrm{La}_{2} \mathrm{O}_{3}$

$\mathrm{Al}_{2} \mathrm{O}_{3}$

$\mathrm{B}_{2} \mathrm{O}_{3}$

$\mathrm{SiO}_{2}$

$\mathrm{SrO}$

Total

\section{Concentration (wt\%)}

$25.0+1-1.00$

$24.9+/-1.00$

$13.5+/-0.50$

$33.7+1-1.00$

$2.9+1-0.25$

100.0

\section{$\underline{\text { Particle Size }}$}

The particle size and/or shape of the 25SrABS glass former have not been finalized but should not impact initial design activities. This is being addressed in the DTTS and the CIM pilot facility. However, particle size and/or shape has been shown to effect volume expansion and/or high-temperature bubble formation. The volume expansion is most prevalent when the particle size of the 25SrABS frit is relatively small (e.g., $<100$ mesh). When coarse $25 \mathrm{SrABS}$ cullet is used, the effects of the volume expansion are minimized, if not eliminated. The exact form/size of the glass former will be specified at the.completion of current glass former testing. However, all forms/sizes under consideration will conform to a specification for a solid pellet/granular form added manually to the melter vessel.

\section{PRODUCT DESCRIPTION}

\section{Nominal Composition}

Table V-1 shows the nominal compositions (in wt\%) of the 25SrABS glass former, the nominal baseline glass composition (AmCm-1a) based on a $47 \mathrm{wt} \%$ Tank 17.3E loading and the most recent material balance calculations [see Material 
Americium-Curium Stabilization - 5" Cylindrical

Induction Melter System Design Basis (U)
SRT-AMC-99-0001

- Revision 0

January 15, 1999

Page 7 of 52

Balance section of SRT-AMC-98-0225, Ref. 5], and the AmCm-1a surrogate composition.

The compositional specifications (or tolerances) that will be allowed in the MPPF have not yet been determined. This is being addressed in a $20 \%$ composition variability study, which is in progress and is scheduled to be completed later this fiscal year. When the compositional variability study and additional CIM tests are completed, the material balance for the batch vitrification process will be updated.

The AmCm-1a surrogate glass is very similar in composition to that estimated as the baseline. There are some minor differences in the relative percentage of the lanthanide oxides. This stems from the fact that the oxides of $\mathrm{Tb}, \mathrm{Dy}, \mathrm{Ho}, \mathrm{Er}, \mathrm{Tm}$, $\mathrm{Yb}$, and Lu appear to be at or below detection limits of the analytical equipment. Assuming that these oxide components are not present in the incoming actinidebearing stream, one can distribute their contribution (2.66 wt\%) over the remaining lanthanide oxides (i.e., increase the other seven $\mathrm{Ln}_{2} \mathrm{O}_{3}$ concentrations by 0.38 wt\%). Previous work has suggested that the total $\mathrm{Ln}_{2} \mathrm{O}_{3}$ concentration is critical, not the distribution although-this will also be addressed in the compositional variability study. This "redistribution" technique keeps the total $\mathrm{Ln}_{2} \mathrm{O}_{3}$ content equivalent to that of the nominal baseline glass (AmCm-1a).

\section{Produict.Density}

The glass density as a function of temperature has not been determined. For material balance purposes, a density of $-3.7 \mathrm{~g} / \mathrm{cc}$ was used to calculate the volume occupied by $1.1-2.0 \mathrm{~kg}$ of glass. For purposes of specifying the canister height, it is recommended that a glass density of $3.5 \mathrm{~g} / \mathrm{cc}$ be assumed. Work is in progress to determine the high-temperature density of the various lanthanide-based glasses.

\section{Product Viscosity -...}

Table V-2 gives the viscosity of $A m C m-1$ a glass surrogate as a function of temperature. These design and operating bases are specified in a subsequent section of this document. It should be noted that the viscosity data for AmCm-1a is limited to a relatively narrow temperature range (approximately $1285^{\circ}-1385^{\circ} \mathrm{C}$ ). This is a result of the steep dependence of viscosity with temperature for the lanthanide borosilicate glasses. Above $1385^{\circ} \mathrm{C}$, the $\mathrm{AmCm}-1$ a viscosity approaches the lower detection limit of the viscometer. Below $1300^{\circ} \mathrm{C}$, crystallization may effect the viscosity measurement due to the liquidus temperature of the glass. 
Americium-Curium Stabilizâtion - 5" Cylindrical Induction Melter System Design Basis (U)

SRT-AMC-99-0001

$\therefore$ Revision 0

January 15, 1999

Page 8 of 52

Table V-1. Actinide-Bearing Feed Material, 25SrABS Frit Composition, and Target Glass Composition ("actual" and surrogate) on an Oxide (wt\%) Basis

\begin{tabular}{|c|c|c|c|c|}
\hline Oxide & $\begin{array}{l}\text { Actinide- } \\
\text { Bearing Feed } \\
\text { Material } \\
\quad \text { (Tank 17.3E) } \\
\end{array}$ & $\begin{array}{c}\text { 25SrABS } \\
\text { Frit } \\
.\end{array}$ & $\begin{array}{c}\text { AmCm-1a } \\
\text { Glass } \\
\text { (47\% loaded) }\end{array}$ & $\begin{array}{c}\text { AmCm-1a } \\
\text { Glass } \\
\text { (surrogate) }\end{array}$ \\
\hline \multicolumn{5}{|c|}{ Lanthanide Oxides } \\
\hline $\mathrm{La}_{2} \mathrm{O}_{3}$ & 15.05 & 25.00 & 20.323 & 20.502 \\
\hline $\mathrm{Ce}_{2} \mathrm{O}_{3}$ & 12.94 & - & 6.082 & 6.260 \\
\hline $\mathrm{Pr}_{2} \mathrm{O}_{3}$ & 11.26 & - & 5.292 & 5.471 \\
\hline $\mathrm{Nd}_{2} \mathrm{O}_{3}$ & 32.80 & - & .15 .416 & 15.595 \\
\hline $\mathrm{Sm}_{2} \mathrm{O}_{3}$ & 7.49 & - & 3.520 & 3.669 \\
\hline $\mathrm{Eu}_{2} \mathrm{O}_{3}$ & 1.56 & - & $\because 0.733 \therefore$ & 0.912 \\
\hline $\mathrm{Gd}_{2} \mathrm{O}_{3}$ & $3.98 \cdots$ & $\therefore-i \cdots \cdots$ & $\because 1.871$ & 2.049 \\
\hline $\mathrm{Tb}_{2} \mathrm{O}_{3}$ & $0.36 \ldots$ & $-\because$ & 0.169 . & 0.00 \\
\hline $\mathrm{Dy}_{2} \mathrm{O}_{3}$ & 0.36 & - & 0.169 & 0.00 \\
\hline $\mathrm{Ho}_{2} \mathrm{O}_{3}$ & 0.36 & - & 0.169 & 0.00 \\
\hline $\mathrm{Er}_{2} \mathrm{O}_{3}$ & 0.35 & - & 0.165 & 0.00 \\
\hline $\mathrm{Tm}_{2} \mathrm{O}_{3}$ & 0.53 & - & 0.249 & 0.00 \\
\hline $\mathrm{Yb}_{2} \mathrm{O}_{3}$ & 0.35 & - & 0.165 & 0.00 \\
\hline $\mathrm{Lu}_{2} \mathrm{O}_{3}$ & 0.35 & - & 0.165 & 0.00 \\
\hline \multicolumn{5}{|c|}{ Actinide Oxides } \\
\hline $\mathrm{Am}_{2} \mathrm{O}_{3}$ & 9.70 & - & 4.559 & $4.559\left(\mathrm{Er}_{2} \mathrm{O}_{3}\right)$ \\
\hline $\mathrm{Cm}_{2} \mathrm{O}_{3}$ & 2.38 & - & 1.119 & $1.119\left(\mathrm{Er}_{2} \mathrm{O}_{3}\right)$ \\
\hline $\mathrm{Np}_{2} \mathrm{O}_{3}$ & 0.00 & - & 0.00 & 0.00 \\
\hline $\mathrm{PuO}_{2}$ & 0.00 & - & 0.00 & 0.00 \\
\hline UO3 & 0.00 & - & 0.00 & 0.00 \\
\hline $\mathrm{Cs}_{2} \mathrm{O}$ & 0.00 & - & 0.00 & 0.00 \\
\hline \multicolumn{5}{|c|}{ Metallic oxides } \\
\hline $\mathrm{Al}_{2} \mathrm{O}_{3}$ & 0.01 & 24.87 & 13.186 & 13.186 \\
\hline $\mathrm{B}_{2} \mathrm{O}_{3}$ & 0.00 & 13.54 & 7.176 & 7.176 \\
\hline $\mathrm{CaO}$ & 0.00 & - & 0.00 & 0.00 \\
\hline $\mathrm{Cr}_{2} \mathrm{O}_{3}$ & 0.00 & - & 0.00 & 0.00 \\
\hline $\mathrm{Fe}_{2} \mathrm{O}_{3}$ & 0.03 & - & 0.014 & 0.014 \\
\hline $\mathrm{K}_{2} \mathrm{O}$ & 0.00 & - & 0.00 & 0.00 \\
\hline $\mathrm{MnO}$ & 0.14 & - & 0.066 & 0.066 \\
\hline $\mathrm{Na}_{2} \mathrm{O}$ & 0.00 & - & 0.00 & 0.00 \\
\hline $\mathrm{NiO}$ & 0.00 & - & 0.00 & 0.00 \\
\hline $\mathrm{SiO}_{2}$ & 0.00 & 33.68 & 17.850 & 17.850 \\
\hline $\mathrm{SrO}$ & 0.00 & 2.91 & 1.542 & 1.542 \\
\hline $\mathrm{ZnO}$ & 0.00 & - & 0.00 & 0.00 \\
\hline $\mathrm{ZrO}_{2}$ & 0.00 & - & 0.00 & 0.00 \\
\hline Total & 100.00 & 100.00 & 100.00 & 100.00 \\
\hline
\end{tabular}


Americium-Curium Stabilization - 5" Cylindrical
Induction Melter System Design Basis $(U)$
SRT-AMC-99-0001

: Revision 0

January 15, 1999

Page 9 of 52

Table V-2. Viscosity of AmCm-1a Glass Surrogate as a Function of Temperature

Temperature $\left({ }^{\circ} \mathrm{C}\right)$

1285

1334

1384
Viscosity (Poise)

22.12

12.38

7.34

\section{Acceptance Criteria}

To ensure that the glass is both processable and meets product performance specifications a set of 'acceptance' criteria have been established for the variability study in order to establish the optimal operating range for the batch vitrification process. These criteria focus on the processing criteria (liquidus temperature and viscosity) and product performance criteria (recoverability and durability).

\section{Processing Criteria}

\section{Viscosity}

Glass viscosity data is critical in establishing the length and internal diameter of the drain tube and the temperature operating parameters to ensure a target glass pour rate of greater than $8.0 \mathrm{~kg} / \mathrm{hr}$ is attained. Expected acceptable viscosities can range from $\sim 3$ to $\sim 30$ poise at $1350^{\circ} \mathrm{C}$. Viscosities outside this range at a fixed temperature will be considered less than optimal due to the potential to result in a non-continuous pour stream (considered to be $<8 \mathrm{~kg} / \mathrm{hr}$ ).

\section{Liquidus Temperature $\left(T_{L}\right)$}

The nominal CIM operating temperatures are in the range of $1350^{\circ}-1450^{\circ} \mathrm{C}$. To avoid the potential negative effects of crystallization within the melter, a liquidus temperature criteria has been set at $1250^{\circ} \mathrm{C}-1350^{\circ} \mathrm{C}$. Lanthanidebased glasses with $T_{L} \leq 1250^{\circ} \mathrm{C}-1350^{\circ} \mathrm{C}$ lower the risk of crystallization in the melter.

\section{Product Performance Criteria}

\section{Durability}

An acceptable durability (as defined by the Product Consistency Test -PCT) is equal to or better than the EA glass limit based on $B$ release (with the 
Americium-Curium Stabilization - 5" Cylindrical

induction Melter System Design Basis (U)
SRT-AMC-99-0001

: Revision 0

January 15, 1999

Page 10 of 52

appropriate confidence limits applied). Typically, $\mathrm{Na}$ and $\mathrm{Li}$ are also tracked, but the SrABS frit does not contain either $\mathrm{Na}$ or $\mathrm{Li}$ and only $\mathrm{Na}$ exists in the waste stream at an extremely low concentration.

\section{Recoverability}

The recoverability criteria is that $98 \%$ of the total lanthanides can be recovered from the glass with concentrated $(15.7 \mathrm{M})$ nitric acid within 2 hours with heating $\left(110^{\circ} \mathrm{C}\right)$ and the glass ground to approximately 60 mesh [Ref. 7].

\section{FLAMMABILITY CONTROL}

Controlled air purges to the various process vessels are required to prevent a flammable hydrogen-air mixture occurring in the vapor space of each vessel. Tanks to be addressed are 17.1, 16.1E, 16.3, 17.3E, Feed Tank, Batch Tank, Precipitator; and Spent Wash Tank. The following equation is used to calculate the scfm of air purge required to limit the hydrogen concentration to $25 \%$ of its Lower Flammability Limit (LFL):

$$
\begin{aligned}
\operatorname{scfm}\left(@ 0^{\circ} \mathrm{C}, 1.0 \mathrm{~atm}\right)= & (\text { Total watts })(6.242 \mathrm{E}+18 \mathrm{ev} / \mathrm{sec}-\text { watt })(\mathrm{G} \text { Value })(3600 \\
& \text { sec/hr })(6.023 \mathrm{E}+23 \mathrm{molecules} / \mathrm{g}-\mathrm{mol})(\{100 /((.25)(\mathrm{LFL}))- \\
& 1\}(22.4 \mathrm{~L} / \mathrm{g}-\mathrm{mol})(60 \mathrm{~min} / \mathrm{hr})
\end{aligned}
$$

where,

- Total watts = see material balance

o. G Value, molecules of $\mathrm{H} 2 / 100 \mathrm{eV}=1.1217 /(1.0+1.702[\mathrm{NO}])$ where $[\mathrm{NO} 3]=$ the nitrate concentration, $M$ [Ref. 8]

- LFL for hydrogen in air $=4.1$ vol\%

The required air purges for each of the above process vessels have been calculated and recorded in the material balance [Ref. 5]. However, if the maximum inventory of a process vessel is different than that listed for that vessel in the material balance calculation bases, the air purge must be scaled to the new process vessel inventory.

\section{CANISTER}

\section{General}

The batch flowsheet process operating parameters (assuming a 5-inch diameter $\mathrm{CIM}$ ) are designed to produce a batch of washed oxalate precipitate which when combined with the proper quantity of glass formers will produce $1.1-2.0 \mathrm{~kg}$ of glass. 
Americium-Curium Stabilization - 5" Cylindrical

Induction Melter System Design Basis (U)

SRT-AMC-99-0001

: Revision 0

January 15, 1999

Page 11 of 52

\section{Design Bases}

- Nominal Internal Diameter - 2.0"

- Minimum wall thickness - to be specified by Design

- Height - to be specified by Design considering required melter freeboard

- Reference Materials of Construction - to be specified by Design

- Nominal glass fill $-1.1-2.0 \mathrm{~kg}$

- Nominal Steady State Centerline Glass Temperature of Canister Filled with 1.1 - $2.0 \mathrm{~kg}$ Glass - $275^{\circ} \mathrm{C}$

- Design Basis Glass Density in Canister at Steady State Temperature - 3.5 to $3.7 \mathrm{~g} / \mathrm{cc}$ (exact density has not been determined and will depend on waste loading)

- External Canister Surface Vertical Temperature During Canister Fill This was determined during glass pours from the 5-inch CIM during Integrated Demonstration Runs and varied from $235^{\circ} \mathrm{C}$ near the top of the canister to $\sim 615^{\circ} \mathrm{C}$ in the area containing glass.

NOTE: Many of these requirements were previously documented [Ref. 9].

\section{CANISTER SCALE}

\section{General}

A canister scale is desired to determine the total weight of glass poured into each canister.

\section{Design Bases}

- Sensitivity $-0.1 \mathrm{~g}$

\section{MELTER FEED PREP}

\section{General}

The pre-treatment process will produce a feed that is nominally $1.0 \mathrm{M}$ in nitric acid and contains nominally 100 grams/L of total solids on an oxide basis. This product stream will undergo additional treatment in the Multi-Purpose Processing Facility (MPPF) to further reduce the nitric acid concentration and transition metal content. The lanthanide and actinide content of the 17.3E feed will be precipitated on a batch basis as oxalates. After allowing the oxalate solids to settle, the supernate will be decanted. Following the addition of a dilute oxalic acid wash solution, the oxalate solids will be agitated, allowed to settle once again and the spent wash decanted. The washed oxalate solids will then be resuspended and transferred by gravity into a Cylindrical Induction Heated Melter (CIM). 
Note: The current process requires that the proper quantity of glass formers has already been charged to the CIM prior to transfer of a batch of washed oxalate solids into the melter from the precipitator:

\section{Feed Tank}

\section{General}

This process vessel will receive transfers from 17.3E for subsequent transfer to the Precipitator Batch Tank. The capacity of this process vessel will depend on how many Precipitator batches the tank is to accommodate. The Design Authority will specify the working volume of this process vessel.

\section{Compositional Control}

It is imperative that the specific gravity of the contents of the Feed Tank remain within the specific gravity tolerance established for 17.3E and for which all process operating parameters have been established in the down stream processes. Because of the high watt density of the feed and the continuous air purge through the vapor space to prevent a flammable atmosphere of airhydrogen, the contents of the Feed Tank will have a tendency to concentrate even with the capability specified to control the temperature of the contents of the Feed Tank. Therefore, continuous monitoring of the specific gravity of the contents is required and the ability to bring the specific gravity to within specifications by periodic water addition is required.

\section{Design Bases}

- Nominal Working Volume - specified by the Design Authority

- Material of Construction - specified by the Design Authority

- Free Board - specified by the Design Authority

- Cooling Coil or Jacket - Design Authority to specify maximum allowable temperature of vessel contents and the design temperature of cooling water supply

- Transfer line from 17.3E

- Overflow Line from Precipitator Batch Tank terminating in Feed Tank vapor space

- Vapor Space Pressure - negative with respect to cell pressure, with pressure requirement to be specified by the Design Authority

- Air Purge - to limit hyärogen concentration in vapor space to $25 \%$ of its LFL

- Agitator - agitator blade configuration and agitator speed to be determined by Design 
Americium-Curium Stabilization - 5" Cylindrical

Induction Melter System Design Basis (U)
SRT-AMC-99-0001

: Revision 0

January 15, 1999

Page 13 of 52

\section{Minimum Services}

- Process Air (to prevent a flammable mixture of hydrogen and air occurring in vessel vapor space)

- Instrument Air - to service pneumatic bubblers

- Process Water (to maintain the SpG within specifications)

- 50 wt\% Nitric Acid (for vessel decontamination)

- Cooling Water to Cooling Coils

- Power (or process air) to agitator

- Vessel Vent (see Stream \#87 in Material Balance for estimated Composition/Flowrate)

\section{Minimum Real Time Monitoring Parameters}

- Temperature of Contents

- Specific Gravity of Contents

- Liquid Level of Contents

- Cooling Water Flow

- Vapor Space Pressure

- Air Purge Rate

- Agitator Speed (or altemative parameter to infer agitator speed)

\section{Recommended Alarms/Interlocks}

- Alarm - HIGH Liquid Level

- Interlock at HIGH-HIGH Liquid Level-stops transfer from 17.3E

- Alarm - HIGH Temperature of Tank Contents

- Alarm - LOW cooling water flow

- Alarm - LOW air purge rate

\section{Precipitator Batch Tank}

\section{General}

The function of this tank is to receive feed from the Feed Tank and deliver a controlled feed batch volume to the Precipitator. This tank will have an overflow to the Feed Tank, which will control the size of the batch transfer volume into the Precipitator Tank. The elevation of the Precipitator Batch Tank must enable gravity draining into the Precipitator.

\section{Design Bases}

- Capacity - specified by the Design Authority

- Nominal Working Volume 
Americium-Curium Stabilization - 5" Cylindrical Induction Melter System Design Basis (U) .
SRT-AMC-99-0001

: Revision 0

January 15, 1999

Page 14 of 52

For 5-inch Diameter Melter - 6.91 Liters

- Overflow Pipe Elevation - to provide nominal working volumes specified above

- Material of Construction - specified by the Design Authority

- Free Board - specified by the Design Authority

- Nominal Operating Temperature of Contents -specified by the Design Authority

- Maximum Temperature of Contents specified by the Design Authority

- Drain Line (with automated valve) to Precipitator

- Cooling Coil or Jacket - Design Authority to specify maximum allowable temperature of vessel contents and the design temperature of cooling water supply

- Vapor Space Pressure - negative with respect to.cell pressure. Pressure requirement to be specified by the Design Authority

- Precipitator Batch Tank Elevation - such that the contents will drain by gravity into the Precipitator

- Air Purge - to limit hydrogen concentration in vapor space to $25 \%$ of its LFL

\section{Minimum Services}

- Process Air (to prevent a flammable mixture of hydrogen and air occurring)

- Instrument Air - to service pneumátic bubblers

- Process Water

- Nitric Acid (50 wt\%) - for vessel decontamination

- Cooling Water

- Vessel Vent (see Stream \# 88 in Material Balance for estimated Composition/Flowrate)

- Power (or process air) to agitator (Note: the current system does not use an agitator)

\section{Minimum Real Time Monitoring Parameters}

- Temperature of Contents

- Liquid Level of Contents

- Cooling Water Flow

- Vapor Space Pressúre

- Air Purge Rate

\section{Recommended Alarms/Interlocks}

- Alarm - HIGH level

- Interlock at HIGH-HIGH Liquid Level - stops transfer from Feed Tank

- Alarm - HIGH Temperature 


\begin{tabular}{lr}
\hline $\begin{array}{l}\text { Americium-Curium Stabilizafion - 5" Cylindrical } \\
\text { Induction Melter System Design Basis }(U)\end{array}$ & $\begin{array}{r}\text { SRT-AMC-99-0001 } \\
: \text { Revision } 0 \\
\text { January 15, 1999 } \\
\end{array}$ \\
\hline
\end{tabular}

- Alarm - LOW cooling water flow

- Alarm - LOW air purge rate

\section{Precipitator}

\section{General}

The function of the precipitator is to provide washed rare-earth/actinide oxalate slurry to the melter while minimizing losses of radioactive species. The oxalate slurry is created in the precipitator by the reaction of the dissolved rareearth/actinide nitrates with oxalic acid to form insoluble oxalates. The precipitation process must be tightly controlled to create a consistent settled solids volume in order to maintain the free solution requirements for transferring the oxalate slurry into the melter without splashing out of the melter. The geometry of the precipitator, the agitation system and the vessel washing system must allow complete gravity draining of the vessel without splashing or solids holdup. All work to date has been performed with a vertical drop line to the melter.

Drawing EES-22674-MO-001 is the recommended design of the precipitator for batching a 5-inch CIM. See Figure IX-1 for a conceptual design of the precipitator.

\section{Cycle}

- Batch Precipitator from Precipitator Batch Tank

- Initiate Agitation

- Bring temperature of batch to $30^{\circ} \mathrm{C}$

- Meter in 8.0 wt\% oxalic acid

- Digest with agitation

- Turn off agitator

- Allow solids to settle

- Decant supernate to Spent Wash Tank

- Add $0.10 \mathrm{M}$ oxalic acid wash

- Initiate agitation

- Digest with agitation

- Turn off agitator

- Allow solids to settle

- Decant spent wash to Spent Wash Tank

- Initiate agitation

- Open drain valve

- Initiate rinse using de-ionized water

- Stop vessel wall rinse and close drain valve (in that order) 
Americium-Curium Stabilizátion - 5" Cylindrical

SRT-AMC-99-0001

Induction Melter System Design Basis (U)

: Revision 0

January 15, 1999

Page 16 of 52

\section{Process Operating Parameters}

$\underline{\text { 5-inch CIM }}$

- Feed Batch Volume, $\mathrm{L}$

6.91

- Precipitant (oxalic acid) Conc., wt\%

8.0

- Precipitant Volume, L

12.2

- Precipitant Temp. , ${ }^{\circ} \mathrm{C}$

$30^{(\mathrm{a})}$

- Precipitant Addition Rate, $\mathrm{ml} / \mathrm{min}$

350

- Precipitation Agitator Speed, rpm

450

- Digestion Period, min

10

- Settling Period, min

30

- Decant Rate, gpm , .

TBD

- Wash (oxalic acid) Conc., M

$0.10^{(\mathrm{b})}$

- Wash Volume, L

7.0

- Wash Period, min

10

- Washing Agitator Speed, rpm

450

(a) Settling, decant and wash may be performed at lower temperature. Control of temperature from $25-60^{\circ} \mathrm{C}$ is desired.

(b) Minimum Concentration $-0.08 \mathrm{M}$

Maximum Concentration $-0.12 \mathrm{M}$

- Settling Period, min

o Mixing Period Prior to Draining, min

1.0

- Vessel Rinse'(water)

DI water

- Vessel Rinse Vol., L

0.267

- Vessel Rinse Addition Rate, $\mathrm{ml} / \mathrm{min}$

800

NOTE: See Figure IX-2 for typical particle size distribution of washed oxalate solids

\section{Design Bases}

Specific

\begin{tabular}{c|} 
5-inch CIM \\
specified by DA \\
specified by DA \\
19.2 \\
specified by DA \\
10.0 \\
30 \\
$6.5 \mathrm{~L}$ level \\
radial turbine \\
2.0
\end{tabular}


Americium-Curium Stabilizafion - 5" Cylindrical

Induction Melter System Design Basis (U)
SRT-AMC-99-0001

: Revision 0

January 15, 1999

Page 17 of 52

- Impeller Dia., in

- Impeller Elevation

- Settled Solids Vol., L

- Total Vol. After Decant, L

- Decant Tube Elev.

- Drain Tube ID, in

- Drain Tube Orientation

- Drain Valve Type

- Nominal Height Drain Tube End Above Melter, in

- Vol. of Settled Solids, LUL Feed
3.0

Solid/Liquid Interface

7.0" above lower impeller

1.9

2.5

to leave volume

noted in prior basis

1.0

vertical

Ball

2.0

0.270

Note: The volume occupied by the settled oxalate solids is a function of the particle size of the solids. The particle size of the oxalate solids is a function of the rate at which the precipitant ( $8.0 \mathrm{wt} \%$ oxalic acid) is added to the feed, the mixing characteristics afforded by the Precipitator's system of agitation, the digestion period and the temperature at which the precipitation and digestion takes place.

\section{General}

- Cold Feed Requirements - see Operating Parameters

The quantities of cold feeds listed in this section are based on $6.91 \mathrm{~L}$ of feed for a 5-inch CIM. If the actual composition of feed in 17.3E differs significantly from that shown in the material balance, the feed volumes will change and these quantities of cold feeds would change accordingly. Cold feeds should be made up with deionized water.

- Precipitator Elevation - must allow gravity draining of the washed precipitate slurry into the Melter. In addition, the precipitator must be able to be moved to clear the outlet from above the melter.

- Cooling Jacket - capable of controlling temperature of Precipitator contents at $25-60^{\circ} \mathrm{C}$. Design Authority to specify design temperature of cooling water supply.

- Vapor Space Pressure - negàtive with respect to cell pressure. Pressure requirement to be specified by the Design Authority

- Air Purge - to limit hydrogen concentration in vapor space to $25 \%$ of its LFL

- Spray Ring or Slinger - design to be developed by Design

Design Criteria - capable of delivering deionized water that completely wets the internal surfaces of the walls of 
the vertical section of the Precipitator. Provisions to also flush the Precipitator with nitric acid are to be provided. This design should be tested in the Pilot Facility.

- Conductivity probe (for HIGH level detection) or other suitable level detection device

\section{Minimum Services}

- Deionized Water

- Process Air (to prevent a flammable atmosphere from occurring)

- Nitric Acid (50 wt\%) - for vessel decontamination

- Cooling water to Cooling Jacket .

- Vessel vent (see Stream \# 89 in Material Balance for Composition)

- 8 wt\% Oxalic Acid

- $0.10 \mathrm{M}$ Oxalic

- 25SrABS glass cullet (see noté below)

Note: This is currently not a requirement. The current flowsheet calls for batching the melter directly with the cullet and batching the washed oxalate slurry on top of the cullet. However, future testing may demonstrate an advantage to blending the cullet with the washed oxalate solids in the precipitator.

- Power (or process air) to agitator

- Power to Conductivity Probe or instrument air if pneumatic bubbler is used for high level detèction

\section{Minimum Real Time Moniforing Parameters}

- Temperature of Contents

- Agitator Speed (or altemative parameter to infer agitator speed)

- Agitator Power

- Agitator Torque

- Vapor Space Pressure

- Air Purge Rate

\section{Recommended Alarms/Interlocks}

- Alarm at HIGH level

- Alarm - loss of Agitation

- Alarm - HIGH Temperature

- Alarm - LOW cooling water flow

- Alarm - LOW Air Purge Rate 
Americium-Curium Stabilization - 5" Cylindrical Induction Melter System Design Basis (U)

SRT-AMC-99-0001

- Revision 0

January 15, 1999

Page 19 of 52

FIGURE IX-1. - Precipitator Tank for 5-Inch CIM

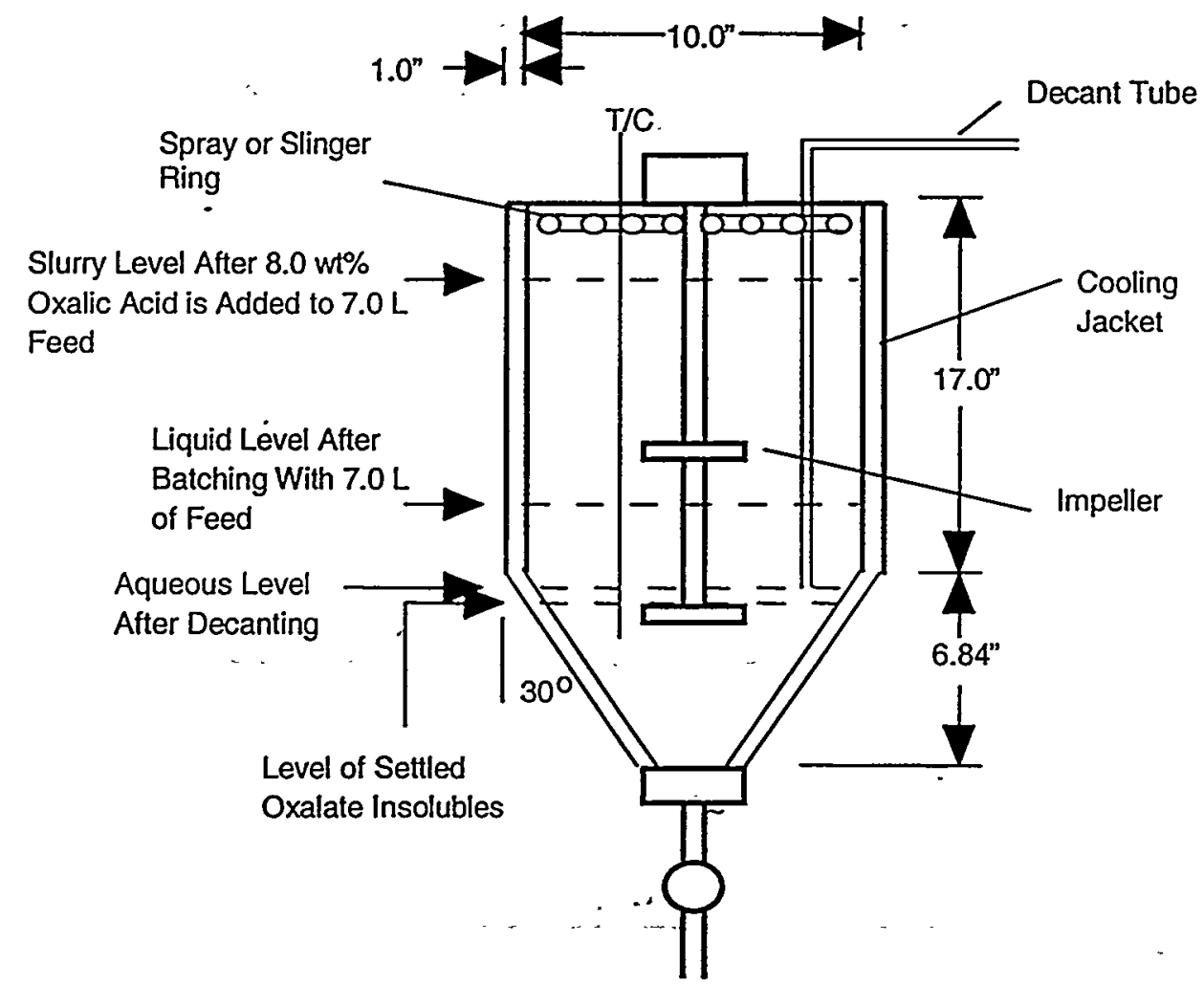

For design bases and operating parameters, see Section IX 
Americium-Curium Stabilizátion - 5" Cylindrical Induction Melter System Design Basis (U)
SRT-AMC-99-0001

: Revision 0

January 15, 1999

Page 20 of 52

FIGURE IX-2. Particle Size Distribution for Washed Oxalate Solids

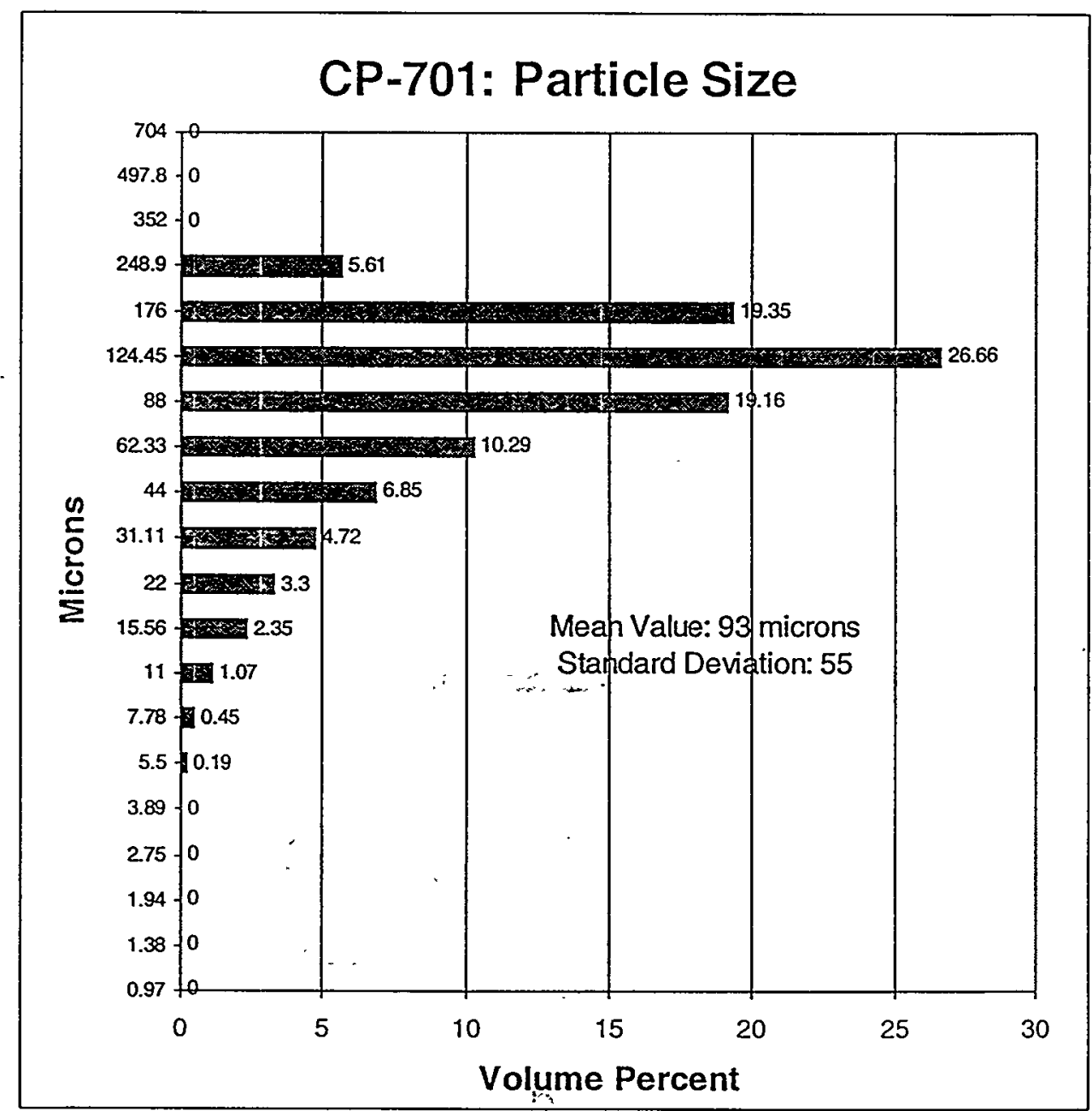

\section{Spent Wash Tank}

\section{General}

The function of this process vessel is to accumulate the supernate and spent wash decanted from the Precipitator. If within radionuclide concentration limits, the contents of the Spent Wash Tank will be transferred into the waste handling system.

The Design Authority will specify the working volume of this process vessel. The total volume of supernate plus spent wash from single Precipitator Batch 


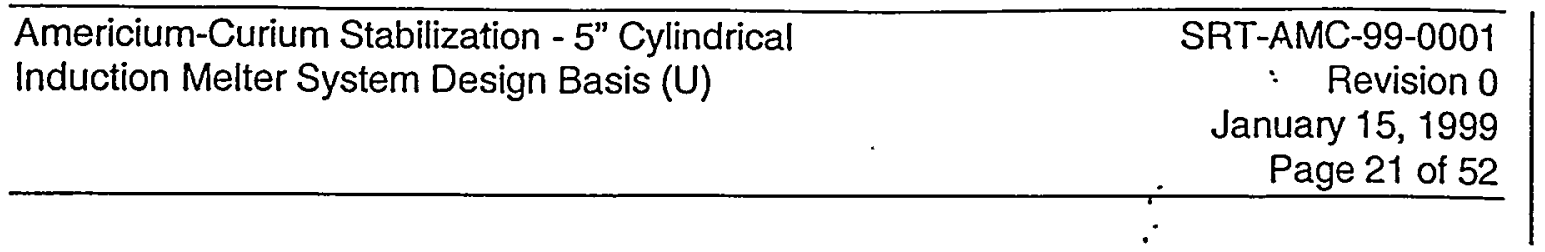

for a 5-inch CIM is approximately 24 Liters. If this process vessel is designed to accommodate the supernate and spent wash from several Precipitator batches, it must be recognized that a single out-of-spec supernate or spent wash batch could contaminate the entire inventory of the Spent Wash Tank.

\section{Design Bases}

- Material of Construction - specified by the Design Authority

- Nominal Working Volume - specified by the Design Authority

- Free Board - specified by the Design Authority

- Process Air (to prevent flammable atmosphere from occurring)

- Sampler

- Transfer line - destination to be specified by Design Authority for contents whose radionuclide content is within limits for disposal as waste.

- Transfer line - destination to be specified by Design Authority for contents whose radionuclide content is outside the limits for disposal as waste

- Transfer line from Precipitator decant tube terminating in vapor space of Spent Wash Tank

- Vapor Space Pressure - negative with respect to cell pressure, prẹssure requirement to be specified by the Design Authority

- Agitator (blade configuration añd speed to be determined by Design)

\section{Minimum Services}

$\therefore \quad$ - Process Ẃater

- 50 wt\% Nitric Acid (for vessel decontamination)

- Vessel Vent (Composition/flow rate not part of Materials Balance)

- Power (or air) to agitator

- Instrument air for pneumatic bubblers

\section{Minimum Real Time Monitoring Parameters}

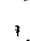

- Temperature of Contents .

- Specific Gravity of Contents

- Liquid Level of Contents

- Vapor Space Pressure

\section{Recommended Alarmsinterlocks}

- Alarm - HIGH level

- Interlock at HIGH-HIGH Level - stops transfer from Precipitator

- Alarm - HIGH Temperature 
Americium-Curium Stabilizátion - 5" Cylindrical

Induction Melter System Design Basis (U)

SRT-AMC-99-0001

$\therefore$ Revision 0

January 15, 1999

Page 22 of 52

\section{VITRIFICATION}

\section{General}

The Cylindrical Induction Melter system installed at TNX is a pilot demonstration version of a more robust and remotely operable system to be installed in the Multipurpose Processing Facility (MPPF). The CIM system is located in 672-T, between the TNX main control room and the IDMS section of the building. It consists of an inductively heated Pt/Rh containment vessel, three Ameritherm, Inc. ${ }^{\circledR}$ induction heating systems and power supplies, a Modicon ${ }^{\circledR}$ control system, a cooling water heat exchanger, and a simple off-gas filtering system. The difference between the CIM and previously tested Am/Cm systems is this Pt/Rh melter vessel is cylindrical in shape and is induction heated, whereas the previous bushing melters were rectangular shaped and direct fired.

An oxalate precipitate produced from the Am/Cm surrogate solution (see Section IX, Melter Feed Preparation), along with 25SrABS glass former, is batched to the melter in a carefully measured mass ratio. Volatilization products and other offgasses are swept into a semi-circular hood positioned above the top of the CIM vessel, then drawn through a moisture separator and high efficiency particulate air (HEPA) filter before being exhausted to the Large Scale SRAT stack. The glass flows from the bottom of the Pt/Rh vessel by gravity through an inductively heated $\mathrm{Pt} / \mathrm{Rh}$ drain tube into a stainiess steel canister. $A$ separate heat exchanger provides cooling water to the induction coils, heat stations and power supplies to prevent overheating. The individual components are described in more detail in subsequent sections.

The induction heating hardware described is based on what Ameritherm:Inc. has designed and installed for the 3-inch CIM system and modified for the 5-inch CIM. Similarly, operating parameters offered have resulted from testing with the 3 -inch and 5-inch CIM systems. Operating data/parameters and facility configuration for the 5-inch CIM only will be discussed in this document.

Note: Design bases and operating parameters are predicated on the assumption that MPPF will not have temperature sensors monitoring the melter contents, melter vessel or drain tube. If pyrometers are proven satisfactory for MPPF-service, their output is considered a monitoring parameter only.

Note: Previous testing with the 3-inch CIM, coupled with the results from heat transfer models, suggested that a third power supply and induction coil could offer a greater advantage in mitigating bed expansion and assuring a more homogenous glass product. Consequently, the 5 -inch CIM was configured with three separate induction coils (and associated heating and coil cooling systems); one for the cylindrical section of the melter, one for the bottom coned portion of the melter and one for the drain tube. 
Americium-Curium Stabilization - 5" Cylindrical

SRT-AMC-99-0001

Induction Melter System Design Basis (U)

- Revision 0

January 15, 1999

Page 23 of 52

\section{CIM5 Batch Vitrification Cycle}

The following describes the nominal process steps executed for the 5-inch CIM Integrated Demonstration Runs [Ref. 6]. (Values in parentheses represent typical power and temperature readings.)

1. Add approximately 676 grams of 25 SrABS CULLET to the CIM5 vessel. Cullet bed height will be approximately 3.25 ".

2. Drop the wet oxalate precipitate slurry from the coupled precipitator into the CIM5 vessel. Allow surrogate solids to settle for 10 minutes, then use the decant pump to decant the free liquid until approximately $1 / 4$ " of free liquid exists above the batch solids bed level. The combined solids bed height will be approximately 8.5 ".

3. Insert a thermowell into the CIM5 vessel, and adjust the placement of the tip of the thermowell to approximately 2.5 - 3 inches from the bottom of the vessel. The tip of the thermowell should be located approximately at the cullet/precipitate interface.

4. Ensure the top insulation cover is removed to provide adequate vapor venting.

5. Energize the drain tube and vessel bottom $5 \mathrm{~kW}$ power supplies, followed by the $20 \mathrm{~kW}$ vessel power supply, at $0 \%$ output. Ensure the READY status is displayed on all three power supply cabinets.

6. Apply power to:the vessel: (XP-20) induction coil by depressing the HEAT ON button on the XP-20 Heat Station control pendant. Adjust vessel power output to $300 / 4095(0.90 \mathrm{~kW})$ to the vessel induction coil to begin bed drying.

7. After 1 hour ( $+/-10$ minutes), reduce the vessel power output to 200/4095 (0.74 $\mathrm{kW}$ ) when the batch solids become visible as the free liquid boils away.

8. After about 10 minutes (when the free liquid has boiled away and batch solids are exposed), apply power to the vessel bottom induction coil by depressing the HEAT ON button on the control pendant. Adjust vessel bottom power output to $200 / 4095(0.31 \mathrm{~kW})$ to achieve subsurface bed drying. Also return the vessel power output to $300 / 4095(0.90 \mathrm{~kW})$.

9. After 50 minutes, when bed drying has been completed, apply power to the drain tube induction coil by depressing the HEAT ON button on the XP- 5 Heat Station 3 control pendant. Maintain the drain tube coil power output at $0 \%$ $(0.14 \mathrm{~kW})$ to ensure any water in the drain tube has been dried.

10. Immediately increase the vessel power output to $350 / 4095(1.02 \mathrm{~kW})$, and increase the vessel bottom power output to $250 / 4095(0.32 \mathrm{~kW})$. 
Americium-Curium Stabilization - 5" Cylindrical Induction Melter System Design Basis (U)
SRT-AMC-99-0001

: Revision 0

January 15, 1999

Page 24 of 52

11. Immediately place the insulating cover over the CIM, leaving a $1 / 2$ " gap to allow for venting $\mathrm{CO}$ that is generated within the batch bed.

After 5 minutes, set the vessel Delta Output to $20 / 4095$ to achieve a nominal temperature ramp of $8^{\circ} \mathrm{C}$ per minute to a target SET TEMP of $900^{\circ} \mathrm{C}$. Adjust vessel power ramp as needed to attain an $8^{\circ} \mathrm{C}$ per minute increase at T1D.

13. After 20 minutes, decrease the vessel Delta Output to $16 / 4095$ to maintain a nominal temperature ramp of $8^{\circ} \mathrm{C}$ per minute as indicated by the vessel wall thermocouple T1D. $\left(\right.$ T1D $\left.\sim 322^{\circ} \mathrm{C}\right)$

14. After 6 minutes, decrease the vessel Delta Output to $14 / 4095$ to maintain a nominal temperature ramp of $8^{\circ} \mathrm{C}$ per minute as indicated by the vessel wall thermocouple T1D. $\left(T 1 D \sim 482^{\circ} \mathrm{C}\right)$

15. After 6 minutes, decrease the vessel Delta Output to $12 / 4095$ to maintain a nominal temperature ramp of $8^{\circ} \mathrm{C}$ per minute as indicated by the vessel wall thermocouple T1D. $\left(T 1 D \sim 534^{\circ} \mathrm{C}\right)$

16. After 20 minutes, decrease the vessel Delta Output to $10 / 4095$ to maintain a nominal temperature ramp of $8^{\circ} \mathrm{C}$ per minute as indicated by the vessel wall thermocouple T1D. $\left(T 1 D \sim 714^{\circ} \mathrm{C}\right)$

17. After 20 minutes, turn RAMP OFF to the vessel coil (at $\sim 1370 / 4095$ vessel power, and $\left.T 1 D \sim 900^{\circ} \mathrm{C}\right)$.

18. Immediately SET the vessel bottom power output to $450 / 4095$.

19. After 5 minutes, reposition the top insulation cover over the CIM so as to reduce thermal losses. (When $\mathrm{T} 3 \mathrm{C}$ has reached $500^{\circ} \mathrm{C}$ )

20. After 20 minutes, SET the vessel bottom power to RAMP ON at 20/4095 Delta Output to a target SET TEMP of $1000^{\circ} \mathrm{C}$. $\left(T 2 A \sim 880^{\circ} \mathrm{C} / \mathrm{T} 2 \mathrm{~B} \sim 820^{\circ} \mathrm{C}\right)$

21. When the vessel bottom power reaches 700/4095 (after $\sim 12$ minutes), turn vessel bottom RAMP OFF, and set vessel RAMP ON at 2/4095 Delta Output to attain $4-6^{\circ} \mathrm{C}$ per minute increases to a SET TEMP of $1400^{\circ} \mathrm{C}$ at T1D.

22. After 10 minutes, increase the vessel Delta Output to $4 / 4095$.

23. After 45 minutes, increase the vessel Delta Output to $9 / 4095$.

24. After 20 minutes, turn the vessel RAMP OFF. 
Americium-Curium Stabilization - 5" Cylindrical Induction Melter System Design Basis (U)
SRT-AMC-99-0001

: Revision 0

January 15, 1999

Page 25 of 52

25. After 5 minutes, RAMP the vessel bottom at.20/4095 Delta Output to attain 4$6^{\circ} \mathrm{C}$ per minute increases to a SET TEMP of $1400^{\circ} \mathrm{C}$.

26. After 6 minutes, increase the vessel bottom power input to $880 / 4095$ and continue RAMP ON at 20/4095 Delta Output. $\left(T 2 A \sim 1234^{\circ} \mathrm{C} / \mathrm{T} 2 B \sim 1198^{\circ} \mathrm{C}\right)$

27. Set vessel RAMP ON to maintain T1D $1400^{\circ} \mathrm{C}$ SET TEMP while the vessel bottom and drain-tube are being brought up to temperature.

28. After 5 minutes, adjust the drain tube power output to $300 / 4095$, then SET the drain tube Delta Output to 50/4095. RAMP ON drain tube to increase the drain tube coil power output to attain approximately $15^{\circ} \mathrm{C}$ per minute temperature increase to $1300^{\circ} \mathrm{C} \mathrm{SET} \mathrm{TEMP} \mathrm{as} \mathrm{indicated} \mathrm{by} \mathrm{the} \mathrm{drain} \mathrm{tube} \mathrm{optical}$ pyrometer, T3A.

29. After 5 minutes, decrease the vessel power output to $1650 / 4095$ while in RAMP ON mode to maintain $\mathrm{T} 1 \mathrm{D} \sim 1400^{\circ} \mathrm{C}$.

30. After 8 minutes, ensure the vessel bottom power input is at least $1200 / 4095$, then increase the Delta Output to $30 / 4095$ to attain $4-6^{\circ} \mathrm{C}$ per minute increases to a SET TEMP of $1400^{\circ} \mathrm{C}$.

31. After 15 minutes, SET the drain tube power input to $1650 / 4095(0.79 \mathrm{~kW})$ and maintain the drain tube in RAMP ON.

32. After $3-6$ minutes, adjust the vessel power input to1600/4095 and maintain the vessel in RAMP ON.

33. Immediately SET the vessel bottom power input to1950/4095 and maintain the vessel bottom in RAMP ON.

34. Ensure the following power inputs are SET as indicated:

Vessel in RAMP OFF at $1600 / 4095(4.40 \mathrm{~kW})$

Vessel bottom in RAMP OFF at $1950 / 4095(2.11 \mathrm{~kW})$

Drain tube in RAMP OFF at $1650 / 4095(0.80 \mathrm{~kW})$

35. When the vessel (T1D) and vessel bottom (T2B) reach $1400^{\circ} \mathrm{C}$, and the drain tube $(\mathrm{T} 3 \mathrm{~A})$ reaches $1300^{\circ} \mathrm{C}$, begin a 30 -minute soak.

36. Maintain the melter vessel át $1400^{\circ} \mathrm{C}(T 1 D)$, the vessel bottom at $1380^{\circ} \mathrm{C}$ to $1400^{\circ} \mathrm{C}(\mathrm{T} 2 \mathrm{~A} / \mathrm{T} 2 \mathrm{~B})$, and the drain tube at $1300^{\circ} \mathrm{C}(\mathrm{T} 3 \mathrm{~A})$ for $1 / 2$ hour to allow bubbles to dissipate from the glass pool.

37. Following the 30-minute soak, initiate the glass pouring sequence to drain the melter vessel contents into a stainless steel canister. 
Americium-Curium Stabilizátion - 5" Cylindrical

Induction Melter System Design Basis (U)
SRT-AMC-99-0001

: Revision 0

January 15, 1999

Page 26 of 52

38. When the pour stream begins to drip or inspection of the vessel indicates the glass level to be no more than $1 / 4$ ", apply the upper drain tube cooling air to terminate pouring.

39. Set the drain tube power input to 0/4095, and then depress the HEAT OFF button on the drain tube XP-5 control pendant.

40. Set the vessel and vessel bottom SET TEMP values to $50^{\circ} \mathrm{C}$, then place both to RAMP ON at 50/4095 to decrease power to cool the CIM vessel.

41. When the vessel and vessel bottom power inputs reach $0 / 4095$, depress the HEAT OFF button on the vessel XP-20 and vessel bottom XP-5 control pendants to de-energize the induction coils and shutdown the system.

\section{Melter Vessel}

\section{Design Bases}

- Dimensional Requirements

- See Figure $X-1$

The CIM5 is a 14" tall cylinder with outside diameter of $5^{\prime \prime}$ and a $0.080^{\prime \prime}$ thick Pt/20Rh wall. The lower 2" of the cylinder is a 45 degree sloped cone. The flat base of the sloped cone is a 1 " diameter circle of Pt/20Rh with a 0.20" I.D. drain tube attached at its center. There exists a $1 / 2$ " wide flange at the extreme top of the 5 " OD cylinder, which supports the cold weight of the vessel when assembled in its support stand.

- Materials of Construction

Pt/20Rh alloy, 0.080" thickness vessel components

$\mathrm{Pt}-\mathrm{Pt} / 13 \mathrm{Rh}$ (R-type) thermocouples (for pilot facility only)

Zircar $^{\otimes}$ insulating sleeve; $3 / 8^{\prime \prime}$ thickness, surrounds vessel cylinder and sloped bottom

- Outside Surface Temperature

See Figure X-2 [Ref. 10]

No measured temperature greater than $125^{\circ} \mathrm{C}$

Note: A similar temperature profile will be obtained for the 5 -inch CIM but is not expected to differ substantially from that developed from the 3-inch CIM. 
Americium-Curium Stabilization - 5" Cylindrical

Induction Melter System Design Basis (U)

SRT-AMC-99-0001

: Revision 0

January 15, 1999

Page 27 of 52

$\therefore$

- Insulating Cover

An insulating cover is placed over the top of the melter after the bed has been dried to reduce thermal losses. In the Pilot System, this cover was a $1 "$ thick block of Kaowool ${ }^{\circledR} 15 \mathrm{C}$.

\section{Minimum Real Time Monitoring Parameters}

- Wall Temperature - See Figure X-3 (for pilot facility only)

Seven (7) Pt-Pt/13Rh R-type thermocouples welded to vessel wall One (1) Mikron ${ }^{\otimes}$ Fiber Optic Infrared temperature transmitter (600 $1700^{\circ} \mathrm{C}$ range)

- Bed/Pool Temperature - See Figure X-3 (recommended for pilot facility only)

Two (2) Pt-Pt/13Rh R-type thermocouples each encased in an 18" long $\mathrm{Pt} / 20 \mathrm{Rh}$ alloy sheath thermowells (\#4A, \#4B)

\section{Recommended Alarms/lnterlocks}

- Alarm HIGH Temperature (as measured by pyrometer and thermocouples) is $1540^{\circ} \mathrm{C}$ (for pilot facility only)

- Interlock Power Off at HIGH-HIGH Temperature (as measured by pyrometer and thermocouples) is $1560^{\circ} \mathrm{C}$ (for pilot facility only)

\section{Heating System}

\section{Melter Vessel}

The melter containment vessel is $80 \%$ platinum $/ 20 \%$ thodium alloy, cylindrically shaped, and heats as a result of exposure to electromagnetic fields generated by the heat station. The vessel is 14 " tall overall, consisting of a $12^{\prime \prime}$ tall by $5^{\prime \prime}$ diameter cylinder, with the bottom $2^{\text {" }}$ tapered to produce a conical transition to the $6^{\prime \prime}$ long by $0.20^{\prime \prime}$ I.D. drain tube welded to the bottom. The vessel wall thickness is $0.080^{\prime \prime}$. The vessel is surrounded by a Zircar ${ }^{\circledR}$ insulating sleeve and water-cooled copper coils through which the electric current is passed which produces the electromagnetic field.

Note: In the pilot facility, seven R-type thermocouples are welded to the vessel wall. Temperature monitoring is also provided by a fiber optic infrared temperature transmitter sensing the infrared energy emitted by the outer Pt/Rh vessel wall. 
Americium-Curium Stabilizátion - 5" Cylindrical Induction Melter System Design Basis (U)
SRT-AMC-99-0001

: Revision 0

January 15, 1999

Page 28 of 52

\section{Melter Vessel and Vessel Bottom (Cone) Power Supplies}

The CIM is heated by two independent induction systems: a $20 \mathrm{~kW}$ heating system for the Vessel Cylinder and a $5 \mathrm{~kW}$ heating system for the Vessel Bottom (Conical) section. The Vessel Cylinder power supply provides up to 20 $\mathrm{kW}$ through the heating station to the vessel heating coils at 350 Volts and 75 Amps dc. The frequency, range supplied to the melter vessel is $50,45,0 \mathrm{kHz}$. The Vessel Bottom (Cone) power supply provides up to $5 \mathrm{~kW}$ through its heating station to the vessel bottom heating coils at 220 Volts and $30 \mathrm{Amps} \mathrm{dc}$. The frequency range supplied to the vessel bottom is $50-450 \mathrm{kHz}$. High temperature alarms and power interlocks are provided which receive input from the four vessel surface-welded thermocouples and single fiber optic infrared temperature transmitter for the 5-inch cylinder, and two wall welded thermocouples at the bottom cone section of the vessel. The power supplies and heating stations are water cooled from a closed-loop chilled water source. Approximately $6 \mathrm{gal} / \mathrm{min}$ water flow for the $20 \mathrm{~kW}$ system and $1 \mathrm{gal} / \mathrm{min}$ for the $5 \mathrm{~kW}$ system at $40-60 \mathrm{psi}$ and $68-95^{\circ} \mathrm{F}$ are required to maintain the power supplies and heat stations at their proper operating temperatures. Alarms and interlocks are present to detect low water flow and high water temperature.

\section{Design Bases}

Melter Induction Coil Configuration - Dimensional Requirements CIM5 Coil Dimensions (See Figure $\mathrm{X}-4$ )

- Material of Construction of Induction Coil $1 / 4$ " Copper tubing, either flat or round (See Figure X-4) The copper tubing supplied by Ameritherm, Inc. ${ }^{\circledR}$ is coated with Gyptol ${ }^{\circledR}$ for electrical isolation and corrosion resistance. The coating for the copper coils in the MPPF will be specified by Design.

- Melter Power Supply Description/Power Capacity $X P-20$ power supply provides up tó $20 \mathrm{~kW}$ at 350 Volts and $75 \mathrm{Amps} \mathrm{dc}$ XP-5 power supply provides up to $5 \mathrm{~kW}$ at 220 Volts and $30 \mathrm{Amps} d \mathrm{c}$ The frequency range supplied is $50-450 \mathrm{kHz}$ (auto load tuning)

\section{$\underline{\text { Services }}$}

- Chilled Water (Total Required) 6.2 GPM @ 40-60 PSI

Chilled Water to XP-20 Power Supply

5 GPM @ 40-60 PSI

Chilled Water to XP-20 Heat Station/Induction Coil

1.2 GPM @ 40-60 PSI 
- Cooling Water Specifications:

$$
\begin{array}{ll}
\text { pH range } & 5.0-9.0 \\
\text { Conductance } & <500 \mathrm{uS} / \mathrm{cm} @ 25^{\circ} \mathrm{C} \\
\text { Resistance } & >2000 \mathrm{OHM} / \mathrm{cm} @ 25^{\circ} \mathrm{C} \\
\text { Supply Temp } & 68^{\circ} \mathrm{F}-95^{\circ} \mathrm{F}\left(20^{\circ} \mathrm{C}-35^{\circ} \mathrm{C}\right)
\end{array}
$$

- Power Supply

$$
440 \text { Volts }-3 \text { Phase required }
$$

\section{Minimum Real Time Monitoring Parameters}

- Cooling Water Supply Temperature $\left(50-120^{\circ} \mathrm{F}\right)$

- Cooling Water Supply Pump Discharge Pressure (0-100 psig)

- Cooling Water Flow to Power Supply (0 - 6 GPM)

- Cooling Water Flow to Heat Station/Induction Coil (0 - 5 GPM)

- Temperature of Chilled Water Exiting Induction Coil $\left(50-120^{\circ} \mathrm{F}\right)$

- Power

- Voltage

- Amperage

- Power Ramp Rate

- Frequency
Range: $0-20 \mathrm{~kW}$

Range: $0-200$ volts

Range: $0-50$ amps

Range: $0-0.5 \%$ per minute

Range: $0-450 \mathrm{kHz}$

\section{Recommended Alarms/lnterlocks}

- Interlock Power Off at LOW-LOW Cooling Water Flow to Power Supply

- Interlock Power Off at LOW-LOW Cooling Water Flow to Heat Station / Induction Coil

- Alarm HIGH Power

- Interlock Power Off at HIGH-HIGH Power

- Alarm HIGH Vessel Wall Temperature at $1540^{\circ} \mathrm{C}$ (pilot facility)

- Alarm at HIGH power ramp rate

- Interlock Power off at HIGH-HIGH Vessel Temperature at $1560^{\circ} \mathrm{C}$ (pilot facility)

\section{Power Ramp Limitation}

- Establish Maximum at $0.5 \%$ Full Power/min

\section{Cooling Water Heat Exchanger Unit}

\section{General}

For the Pilot System, cooling water for the vessel and drain tube induction power supplies, heat stations and coils is provided by a closed loop cooling 
Americium-Curium Stabilizátion - 5" Cylindrical Induction Melter System Design Basis (U)
SRT-AMC-99-0001

: Revision 0

January 15, 1999

Page 30 of 52

system. A Koolant Kooler ${ }^{\circledast}$ unit provides cooling water at the necessary temperature and pressure to meet the requirements of the CIM induction heating system. Copper piping and plastic tubing are used to transfer the cooling water between the chiller and induction equipment. A sight glass is used to ensure adequate water level is maintained within the chiller reservoir. Internal controls cycle the cooling fans as needed to maintain the cooling water to within $2^{\circ} \mathrm{F}$ of the desired temperature. The pump operates constantly to deliver the required water flow and pressure. The setpoint of the chiller is adjusted to maintain the coil heat station and power supply temperatures above the ambient dew point temperature to prevent condensation and the associated electrical problems.

\section{Design Bases}

- Capacity

- Discharge Pressure

- Internal Low Press Switch

- Water Quality

- Filtration Requirement
$59,000 \mathrm{BTU} / \mathrm{Hr}$

$40-60$ psig

in at $50 \mathrm{psig}$, out at $25 \mathrm{psig}$

$5.0-9.0 \mathrm{pH},<500 \mathrm{uS} / \mathrm{cm}$

Standard process water filter

\section{Services}

- Distilled Water

- Power

- Cabinet ventilation

- Distilled Water Leak Detection Capability in Cabinet
33 Gallon Reservoir Capacity $460 \mathrm{Volts} / 3$ phase $/ 60 \mathrm{~Hz}$ maintain $50^{\circ} \mathrm{F}-80^{\circ} \mathrm{F}$ ambient temp in cabinet

\section{Recommended Alarms/lnterlocks}

- Alarm at LOW chilled water flow as indicated by internal flow switch

- Interlock Power Off at LOW-LOW chilled water flow as indicated by internal flow switch 
Americium-Curium Stabilization - 5" Cylindrical Induction Melter System Design Basis (U)

SRT-AMC-99-0001

: Revision 0

January 15, 1999

Page 31 of 52

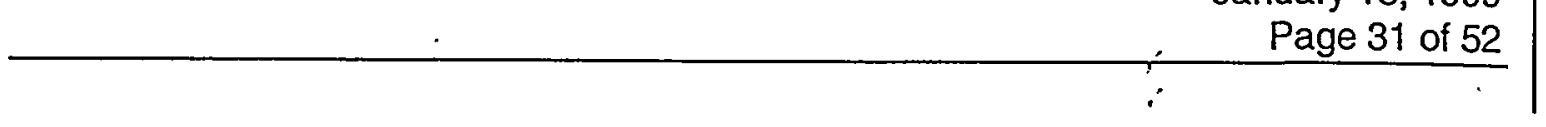

Figure X-1. 5-Inch CIM Vessel

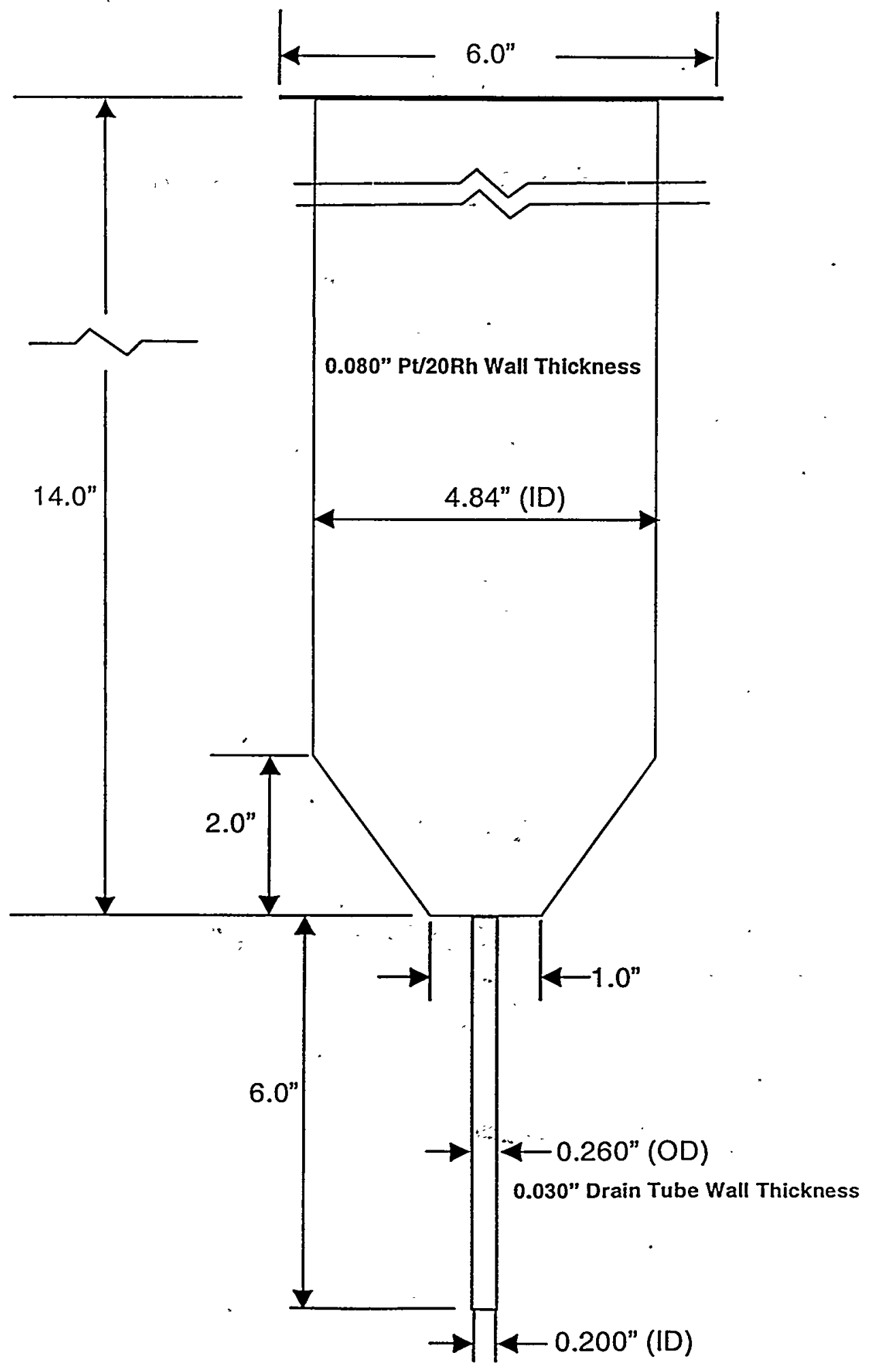




\begin{tabular}{|c|c|}
\hline $\begin{array}{l}\text { Americium-Curium Stabilizátion - 5" Cylindrical } \\
\text { Induction Melter System Design Basis }(U)\end{array}$ & $\begin{array}{r}\text { SRT:AMC-99-0001 } \\
: \quad \text { Revision } 0 \\
\text { January } 15,1999 \\
\text { Page } 32 \text { of } 52 \\
\end{array}$ \\
\hline
\end{tabular}

Figure X-2. 3-Inch CIM Outside Surface Temperatures

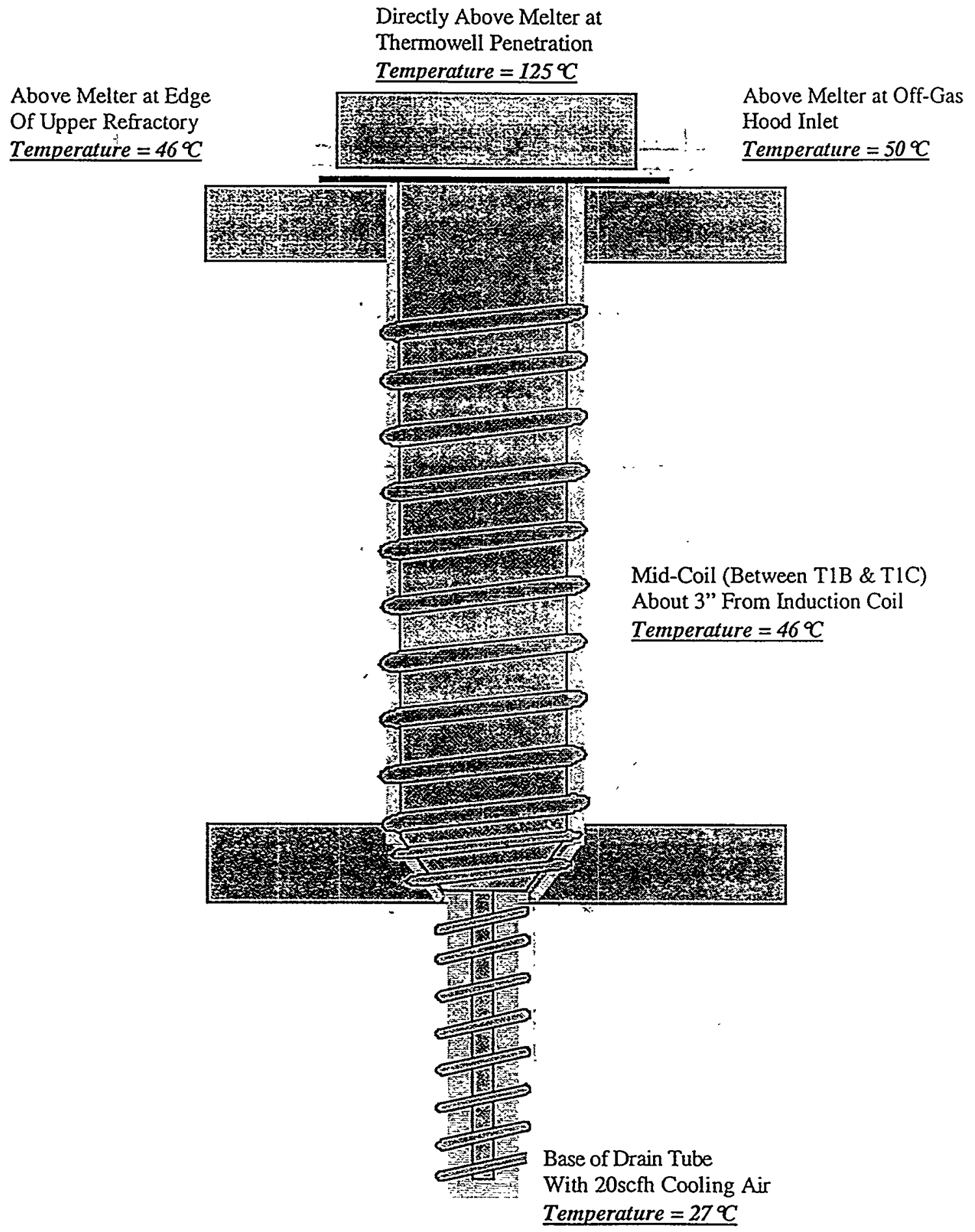


Americium-Curium Stabilization - 5" Cylindrical

Induction Melter System Design Basis (U)
SRT-AMC-9:-0001

- Revision 0

January 1E, 1999

Page 3-3 of 52

Figure X-3. 5-Inch CIM Temperature Measurement Locations

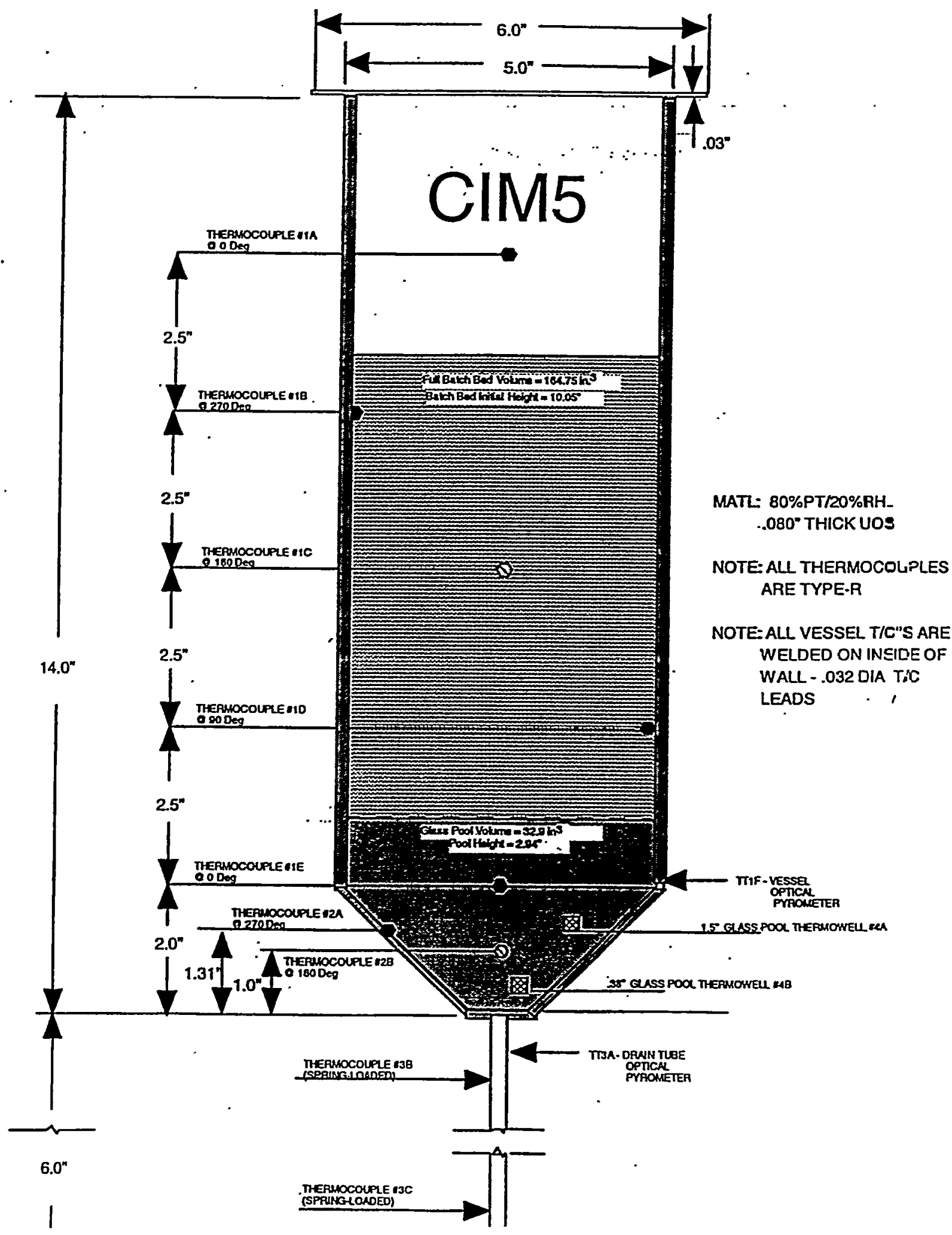


Americium-Curium Stabilization - 5" Cylindrical Induction Melter System Design Basis (U)
SRT-AMC-99-0001

Revision 0

January 15, 1999

Page 34 of 52

Figure X-4. 5-Inch ClM Coil Configuration

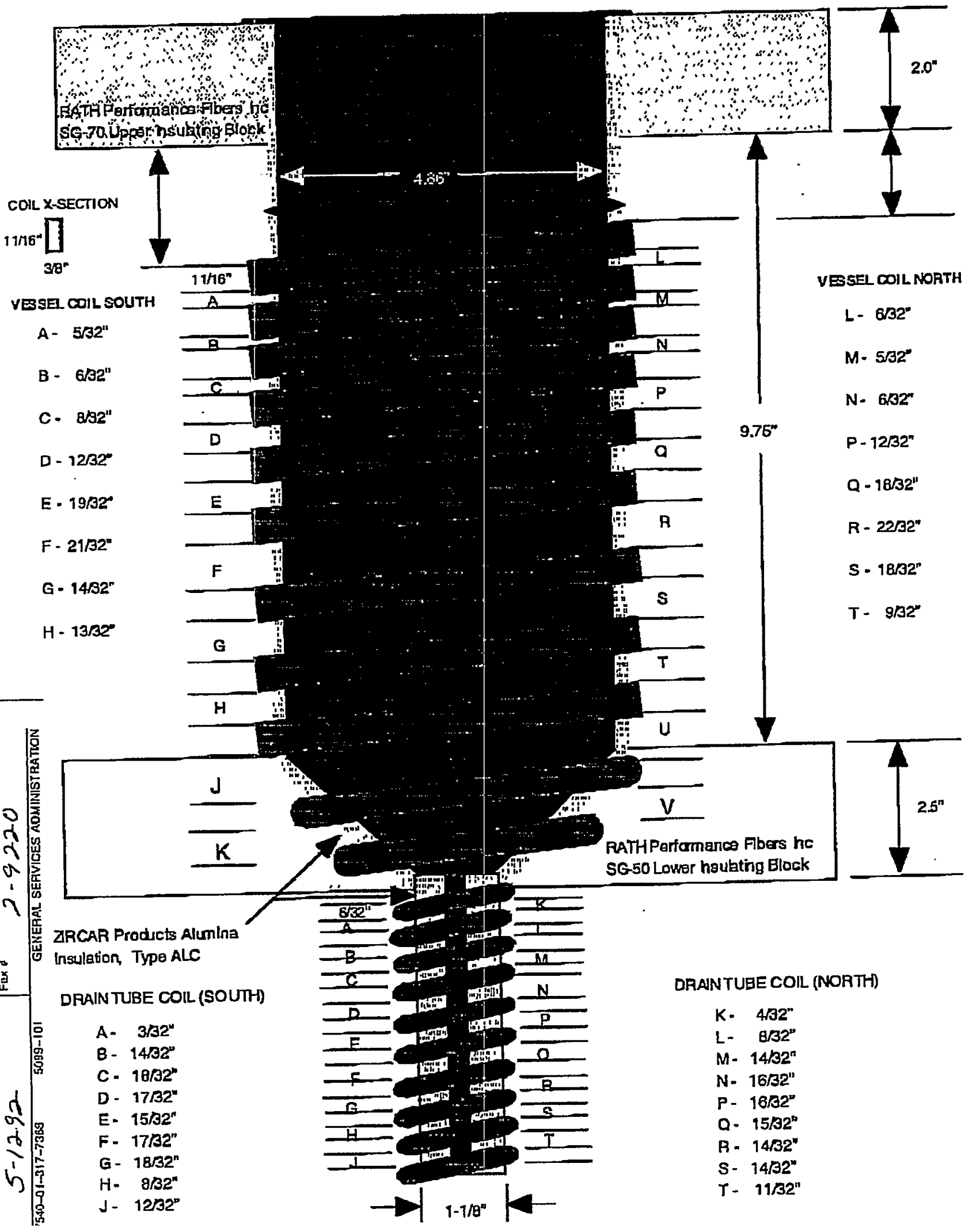


Americium-Curium Stabilization - 5" Cylindrical

Induction Melter System Design Basis (U)

SRT-AMC-99-0001

: Revision 0

January 15, 1999

Page 35 of 52

XI. GLASS POURING

\section{General}

The 5" Cylindrical Induction Melter (CIM) employs a drain tube located on the bottom of the melter vessel to pour glass into the canister. The nominal 0.20 " I.D. $80 \%$ platinum- $20 \%$ rhodium drain tube is $6^{\prime \prime}$ long and has a wall thickness of 0.030 ". The drain tube is inductively heated by the drain tube power supply, which provides up to $5 \mathrm{~kW}$ through the heating station to the drain tube heating coils, at 300 volts and 20 amps dc. High temperature alarms and interlocks are provided through spring loaded thermocouples at two elevations on the tube and a pyrometer (in the pilot facility). User programmable power clamps are also are provided through the. FactoryLink ${ }^{\circledR}$ control system interface. Both the drain tube power supply and drain tube heating station are water cooled from a closed-loop chilled water system. Approximately $1 \mathrm{gal} / \mathrm{min}$ water flow at $40-60 \mathrm{psi}$ and $68-95^{\circ} \mathrm{F}$ is required to maintain the power supply and heat station at their proper operating temperatures. Alarms and interlocks are present to detect low water flow and high water temperature conditions. Cooling air for stopping glass flow through the drain tube is supplied through two pair of tubes, at flow rates up to $180 \mathrm{SCFH}$ per pair.

The field workstation is also used to control the drain tube heat station power output, either by manual setpoint (\% power), or incrementally ramped power increases to a target temperature. Based on Pilot System testing, percent power is the recommended control parameter for the drain tube.

The sequencing of the cooling air applied to the drain tube is controlled by the FactoryLink ${ }^{\otimes}$ workstation in the pilot facility.: Timer values for the length of time the Upper Cooling Air is applied and the delay prior to Lower Cooling Air application upon initiating a glass pour stop sequence may be selected by the operator, allowing pour stopping to be controlled consistently. Pushbuttons are also available for documenting the time various pouring events occur, such as glass plug movement, glass plug drop, glass stream initiation, stream dripping upon glass stopping, and glass stopped. '

The induction heating hardware described in the following subsections is based on what Ameritherm Inc. has designed and installed for the single drain tube only heating coil. Similarly, the operating parameters discussed reflect the 5-inch CIM with the three independent zones (vessel sidewall, vessel cone and drain tube heating only).

Design bases and operating parameters shown below include reference to temperature sensor monitoring of the drain tube walls. Temperature monitoring using standard Type-R thermocouples spring loaded at the drain tube wall and an optical pyrometer has not proven to be reliable, and is not recommended for use as bases for design or operation. Instead, power is used as the control parameter and is considered extremely reliable and is proven repeatable. 
Note: If infrared pyrometers are proven satisfactory for service in MPPF, they should be considered an informational reference parameter only.

\section{Cycle}

The methodology employed to drain a vitrified batch from the CIM requires that heat be applied uniformly over the entire length of the drain tube, and requires methods of holding the glass in the drain tube until the pour sequence is initiated and for stopping the molten glass stream at the end of a pour. The drain tube is heated using the induction heating equipment at rates ranging from $12^{\circ} \mathrm{C}$ per minute to $25^{\circ} \mathrm{C}$ per minute to a drain tube wall temperature of approximately $1350^{\circ} \mathrm{C}$. Data shows that pour initiations (starts) are easily achievable within 90 seconds of the removal of the lower holding air at a drain tube power of - approximately $0.84 \mathrm{~kW}$. Optical pyrometer temperature measurements approximately one and one-half to two inches below the flat bottom of the melter vessel cone section are in the 1350 to $1370^{\circ} \mathrm{C}$ range once holding air is removed (at pour initiation). Pour rates for a melter vessel temperature in the 1400 to $1480^{\circ} \mathrm{C}$ range are between 12 to 18 kilograms per hour (assuming a homogenous vitrification product). A pour is considered complete at the onset of a discontinuous (dripping) pour stream. Stopping the pour is accomplished by applying cooling air for 30 seconds to the upper portion of the drain tube and applying holding air after 15 seconds to the tip of the drain tube: During the pouring operation, the drain tube power supply is typically held at $100 \%$ of the power required to pour (in this case $0.84 \mathrm{~kW}$ ). Power is immediately dropped by approximately $0.25 \mathrm{~kW}$ (200/4095) and then ramped down at up to $30^{\circ} \mathrm{C}$ per minute following the stopping of a pour.

\section{Pouring Sequence}

- Position canister beneath drain tube

- Tare canister

- Assure drain tube tip holding air is on and upper tube cooling air is off

- Set maximum power at $1.0 \mathrm{~kW}$ (Note: Full power for the system installed is $5 \mathrm{~kW}$ )

- 'Begin drain tube power ramp sequence (as outlined below) Once the drain tube power ramp sequence is complete, turn off drain tube tip holding air to initiate plug drop

- At the end of the pour (as indicated by discontinuous pour rate), turn on cooling air to the upper portion of drain tube for 30 seconds followed by the lower holding after 15 seconds. [Pour stopping is provided by the CIM workstation as an automatic time based sequence of Upper Cooling Air followed by Lower Holding Air.] 
Americium-Curium Stabilization - 5" Cylindrical

SRT-AMC-99-0001

Induction Melter System Design Basis (U)

: Revision 0

January 15, 1999

Page 37 of 52

Drain Tube Power Ramp Sequence

The following is the typical drain tube power ramp sequence used during the 5inch CIM Integrated Demonstration Runs [Ref. 6].

1. Ensure the drain tube power supply is in idle, 0/4095, HEAT ON

2. After 5 minutes, manually input $300 / 4095$, and set the following parameters:

- Delta Output $\quad=50 / 4095$

- Output Setpoint $=1650 / 4095$

- Ramp Function = ON

3. After approximately 49 minutes (54 minutes elapsed, includes: 5 minute HEAT ON idle, 27 minutes to ramp to setpoint and 22 minutes for melter cone and vessel wall power to stabilize), set the ramp function to OFF, and begin 30 minute pre-pour soak

4. Initiate draining by maintaining the drain tube coil power at $0.84 \mathrm{~kW}$ and remove the Upper Cooling Air

Note: Figure $\mathrm{XI}-1$ illustrates the drain tube power based ramp sequence as demonstrated during the CIM5 Integrated Runs.

\section{Drain Tube}

\section{Design Bases}

- The general drain tube configuration is shown in Figure XI-2. The drain tube/insulation tube/heating coil space requirements installed in the pilot facility have proven important in avoiding glass accumulation on the insulation tube while maintaining adequate heat applied to the tip. In is considered generally desirable to allow the tip of the Pt/Rh drain tube to extend slightly below the insulation tube when cold $\left(-1 / 8^{\prime \prime}\right)$. However, the tip of the tube should still be recessed above the lower edge of the lowest coil by approximately $1 / 8^{\text {"n }}$ when hot. Figure XI-3 graphically depicts the vertical spacing relationship between the drain tube, insulation tube and the coil.

Note:The length and internal diameter of the drain tube has been developed from drain tests with oils, field testing, and computer modeling.

- Materials of Construction: $80 \%$ Platinum / $20 \%$ Rhodium Alloy

0.20 " I.D.

$0.030^{\prime \prime}$ wall thickness

6.0 " length 


\begin{tabular}{|c|c|}
\hline $\begin{array}{l}\text { Americium-Curium Stabilization - 5" Cylindrical } \\
\text { Induction Melter System Design Basis (U) }\end{array}$ & $\begin{array}{r}\text { SRT-AMC-99-0001 } \\
: \quad \text { Revision } 0 \\
\text { January } 15,1999 \\
\text { Page } 38 \text { of } 52\end{array}$ \\
\hline
\end{tabular}

- Insulation Requirements: A Zircar insulation sleeve with a wall thickness of $\sim 0.25$ " surrounds drain tube (See Figure XI-2)

- Two Upper Cooling Air Ports @ $180^{\circ}$ Apart Directed at Top of Drain Tube

$>$ Nominal Air Flow per Port - 50 cfh @ 35 psig @ $25^{\circ} \mathrm{C}$

- Two Lower Holding Air Ports @ $180^{\circ}$ Apart Directed at Tip of Drain Tube

$>$ Nominal Air Flow per Port - $10 \mathrm{cfh} @ 35 \mathrm{psig} @ 25^{\circ} \mathrm{C}$

- Canister to be centered under the drain tube with top of canister no further than 3 inches and no closer than 2 inches from the lowest edge of the induction coil (approximately two coil diameters from the induction coil)

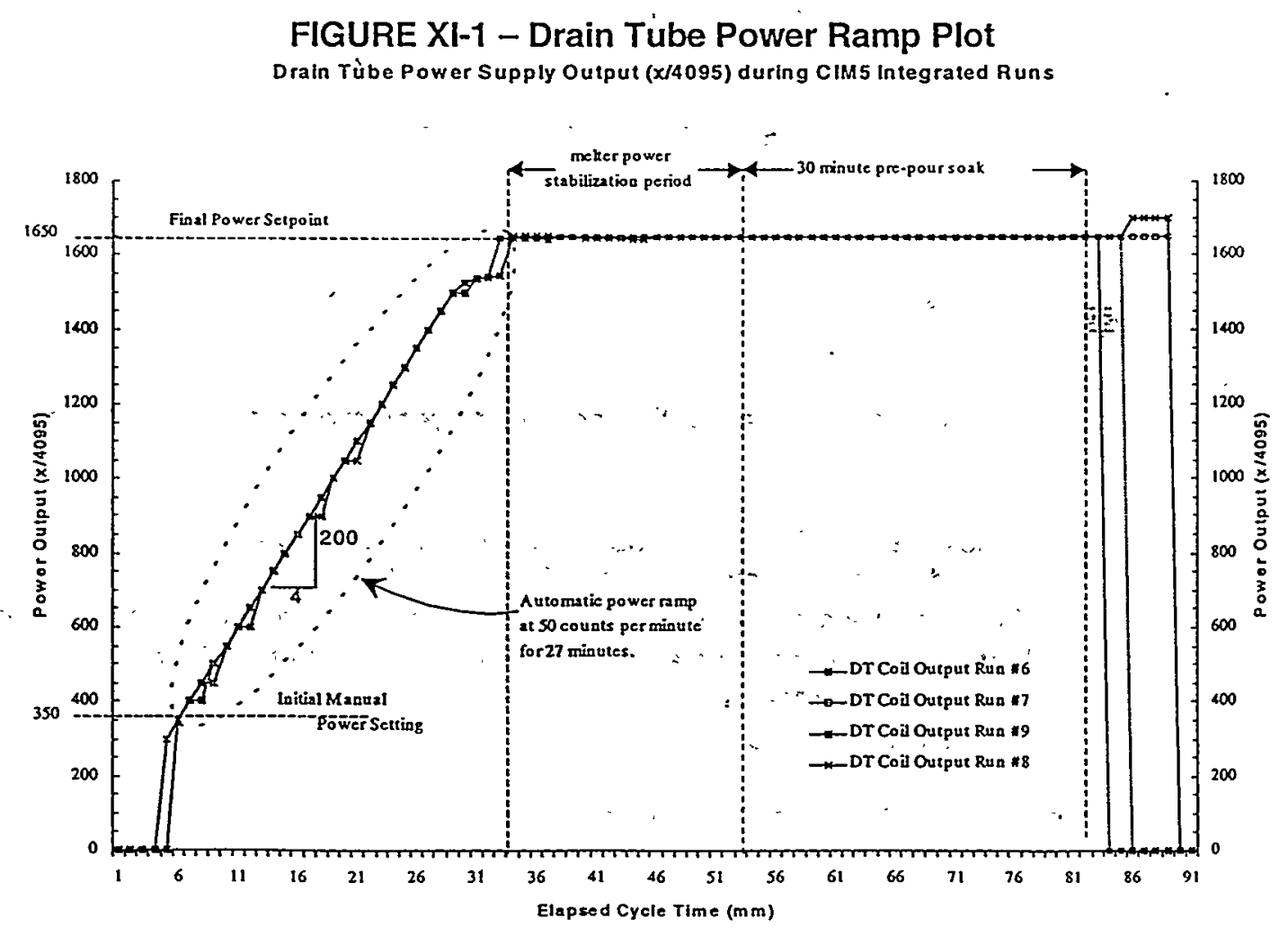


Americium-Curium Stabilizafion - 5" Cylindrical
Induction Melter System Design Basis (U)
SRT-AMC-99-0001

: Revision 0

January 15, 1999

Page 39 of 52

\section{FIGURE XI-2 - Drain Tube Configuration}

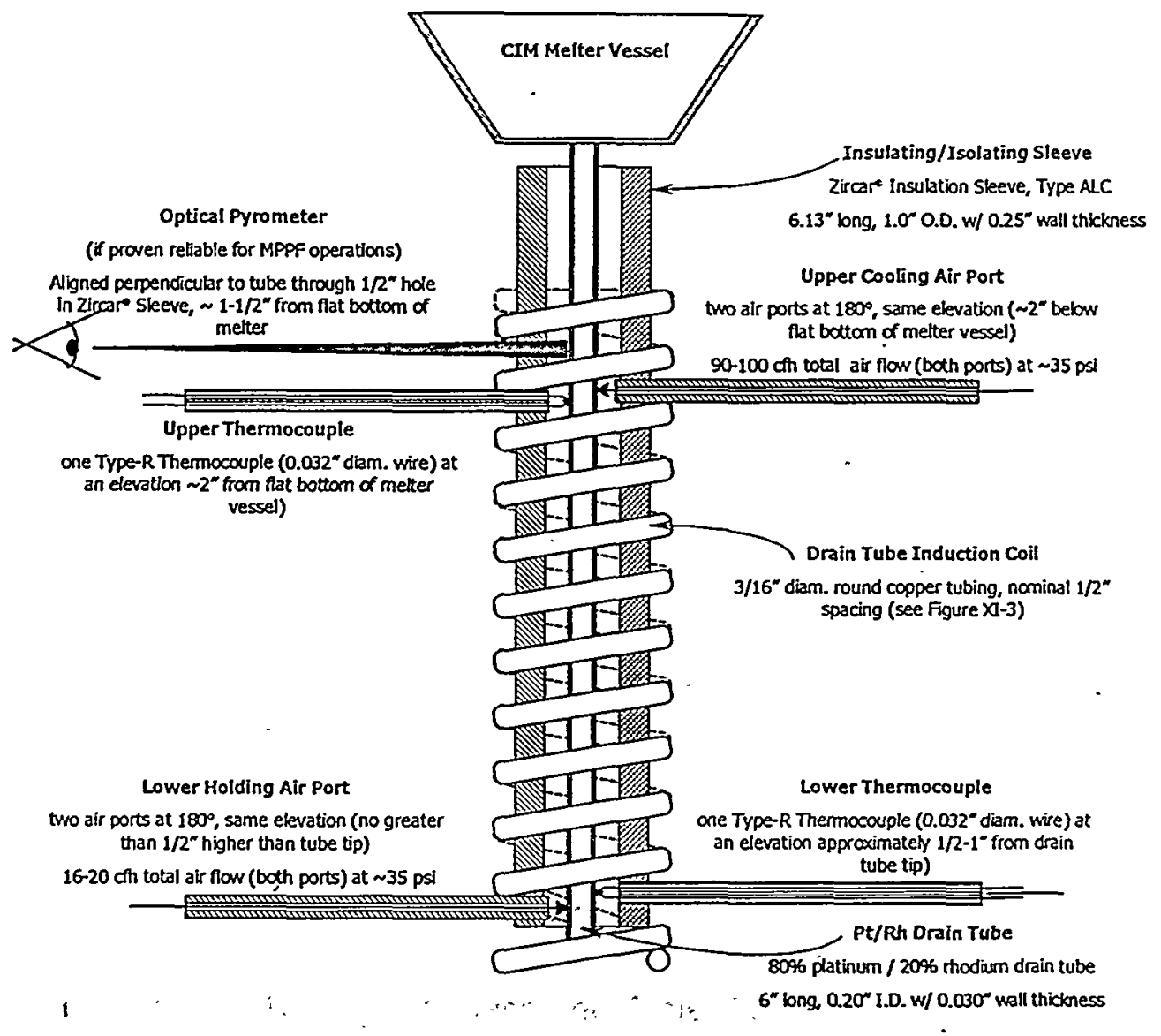

\section{Minimum Real Time Monitoring Parameters}

As discussed above, the drain tube sequence is controlled by power to the induction coil. In the Pilot System, temperature measurement devices are also used. However, these devices are somewhat unreliable do to movement of the drain tube during the processing cycle. The Design Authority will determine whether these devices are included in the MPPF design.

- Tube Wall Temperatures (see Figure XI-2) for pilot facility only

One (1) Mikron ${ }^{\oplus}$ Fiber Optic Infrared temperature transmitter 600 $1700^{\circ} \mathrm{C}$ range is provided. Reliability due to slight movements of the tube through the heating process is questionable. 
Two (2) Type-R Thermocouples $\left(50-1760^{\circ} \mathrm{C}\right)$ using ceramic doublebore isolation tubes are spring loaded against the drain tube. One each is located at upper and lower elevations on the drain tube wall. All are considered unreliable.

FIGURE XI-3 - Graphic Representation of Spacing Relationship of Drain Tube to Insulation Tube and to Coil

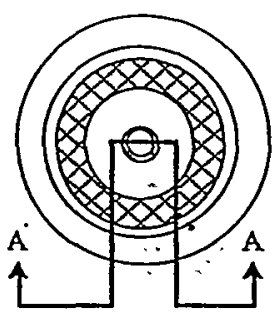

Lower edge of the drain tube to extend BELOW the lowe Edge of the Zincare Insulation Tube when cold (by $\sim 1 / 8^{\circ}$

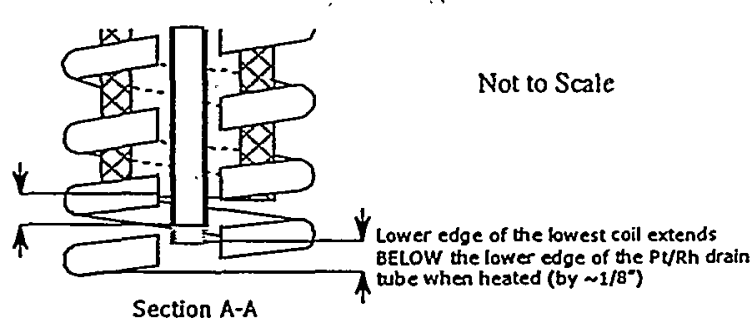

\section{Services}

- Cooling Air to Drain Tube Lower Holding Air Ports (lower air)

- Cooling Air to Drain Tube Upper Cooling Air Ports (upper air)

\section{Recommended Alarms/Interlocks}

- Alarm HIGH Temperature (às measured by the pyrometer): $1500^{\circ} \mathrm{C}^{*}$

- Interlock Power Off at HIGH-HIGH Temperature (as measured by the pyrometer): $1560^{\circ} \mathrm{C}^{\star}$.

${ }^{*}$ Assuming the pyrometer used is ranged $600-1700^{\circ} \mathrm{C}$ 
Americium-Curium Stabilization - 5" Cylindrical Induction Melter System Design Basis (U)

\section{Heating System}

\section{General}

The induction system is comprised of an Ameritherm $5 \mathrm{~kW}$ Power Supply, a heat station and an induction coil. This section is a general description of the Drain Tube Induction heating system using a single coil on the tube only.

Note: Although additional configurations of the drain tube induction coil have been tested, this section addresses only the single, drain tube coil option.

\section{Design Bases}

Drain Tube Induction Coil Configuration - Dimensional Requirements (see Figure XI-4)

- Material of Construction: 3/16" O.D. Coated Round Copper Tubing The copper tubing supplied by Ameritherm, Inc. ${ }^{\circledast}$ is coated with Gyptol ${ }^{\otimes}$ for electrical isolation and corrosion resistance. The coating for the copper coils in the MPPF will be specified by Design.

- Drain Tube Induction Heater Power Supply (Ameritherm ${ }^{\otimes}$ XP-5 Power Supply)

$>5 \mathrm{~kW}$

$>300$ Vólts dc

$>20$ Amps dc

$>50-450 \mathrm{kHz}$ (auto load tuning)

*Frequency operates at $\sim 217 \mathrm{kHz}$ for 5 " CIM configuration.

\section{Services}

- Chilled Water Total: 1.0 GPM @ 40 - 60 psi

$$
\begin{aligned}
& \text { Chilled Water to XP-5 Power Supply } \\
& \text { >0.5 GPM @ } 40-60 \text { psi required } \\
& \begin{array}{c}
\text { Chilled Water to Heat Station/lnduction Coil } \\
>0.25 \text { GPM @ } 40-60 \text { psi required }
\end{array}
\end{aligned}
$$

- Power Supply: 480 volts - 3-phase required

\section{Minimum Real Time Monitoring Parameters}

- Chilled Water Supply Temperature:

- Chilled Water Pump Discharge Pressure:

- Chilled Water Flow to Power Supply:

Range: $50-120^{\circ} \mathrm{C}$

Range: $0-100$ psig

Range: $0-2$ GPM 


\begin{tabular}{lr|}
\hline $\begin{array}{l}\text { Americium-Curium Stabilizátion - 5" Cylindrical } \\
\text { Induction Melter System Design Basis (U) }\end{array}$ & $\begin{array}{r}\text { SRT-AMC-99-0001 } \\
: \text { Revision } 0 \\
\text { January 15, 1999 } \\
\text { Page 42 of 52 }\end{array}$ \\
\hline
\end{tabular}

- Chilled Water Flow to Heat Station/Induction Coil: Range: $0-1$ GPM

- Temp of Chilled Water Exiting Induction Coil: Range: $50-120^{\circ} \mathrm{F}$

- Power:

- Voltage:

Range: $0-5 \mathrm{~kW}$

- Amperage:

Range: $0-300$ volts

j. - Frequency

Range: $0-20$ amps

FIGURE XI-4 - Drain Tube Induction Coil Dimensions

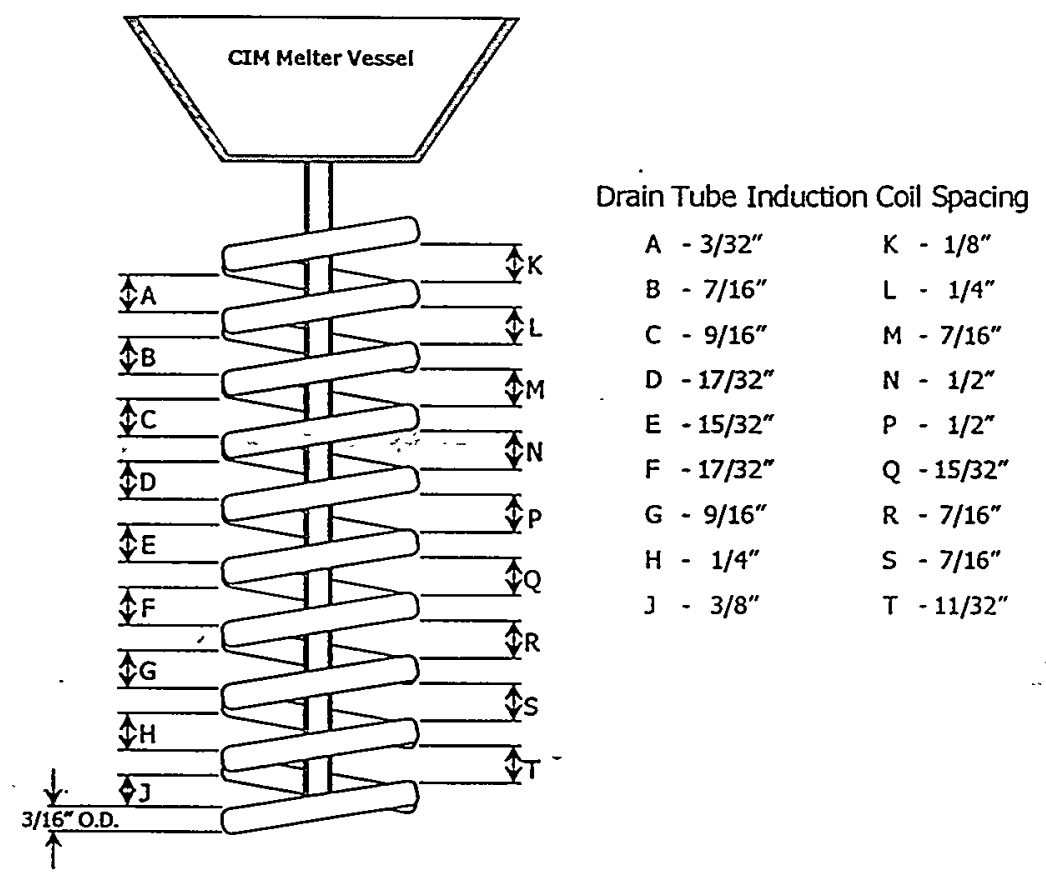

Recommended Alarms/Interlocks

- Alarm LOW Chilled Water Flow to Power Supply

- Interlock Power Off at LOW-LOW Chilled Water Flow to Power Supply

- Alarm LOW Chilled Water Flow to Heat Station/Induction Coil

- Interlock Power Off at LOW-LOW Chilled Water Flow to Heat Station

- Alarm HIGH Power: $\geq 1.2 \mathrm{~kW}$

- Interlock Power Off at HIGH-HIGH Power: $\geq 1.4 \mathrm{~kW}$ 


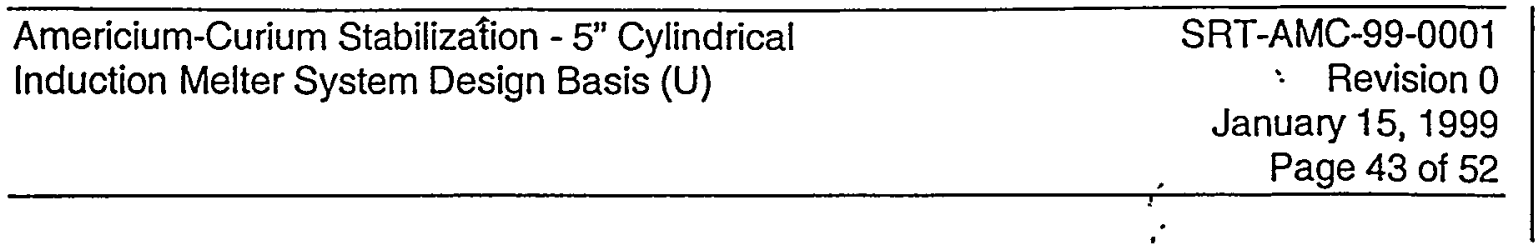

\section{Power Ramp Limitation}

- Established at a maximúm of $2 \%$ full power/min (80/4095 per minute)

\section{Cooling Water Heat Exchanger Unit}

See Section X - Cooling Water Heat Exchanger Unit

\section{MELTER OFF-GAS TREATMENT .}

\section{General}

The current concept for the melter off-gas system consists of a hood located above and to the side of the circular top opening of the melter vessel. The exact location (distance above and radial distance away from the circular cross section of the melter vessel) and the cross sectional area of the hood, are to be determined by design to meet the design bases. This hood is open to the cell atmosphere and is to be designed to sweep process gasses and entrainment exiting the melter into the off-gas system.

The melter off-gas drawn into the hood passes through an off-gas line to a moisture separator. This moisture sèparator removes any water that may condense prior to addition of dry dilution air into the off-gas stream. Downstream of the moisture separator, a dry air stream is added to the off-gas to reduce the dew point of the off-gas to at least $10^{\circ} \mathrm{C}$ below the off-gas temperature (after mixing with the dry air). The off-gas is then passed through a HEPA filter before discharge into the appropriate MPPF Process Vessel Ventilation System.

Note: Design Basis Decontamination Factor across Melter Off-Gas System to be specified by the Design Authority.

\section{Melter Ventilation Exhaust Hood}

\section{Design Bases}

- Minimum Centerline Horizontal Air Velocity Across Melter Top - 250 $\mathrm{ft} / \mathrm{min}$

This velocity is defined as the arithmetic average of the centerline velocity at the near $(N)$ and far $(F)$ edges of the melter top, as shown below. 


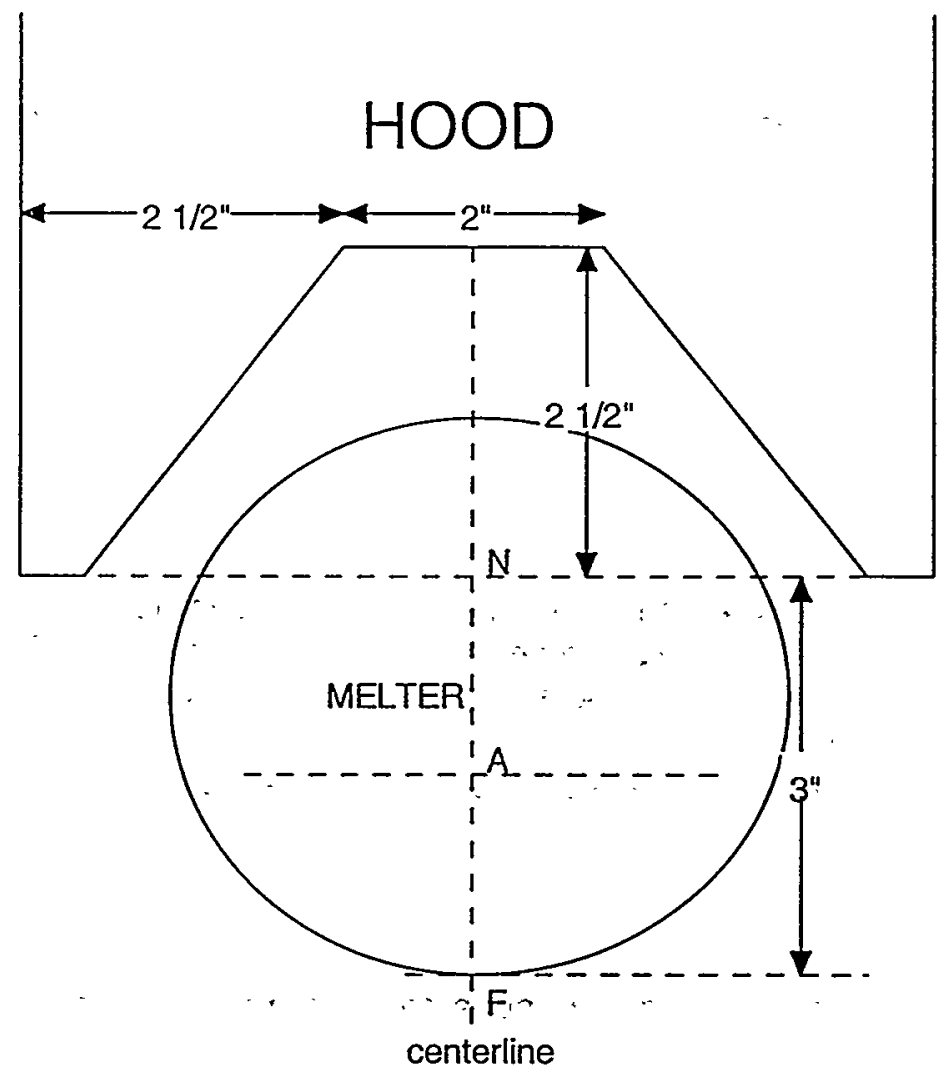

- Minimum Volumetric Flow into Hood -30 scfm at $100 \%$ relative humidity

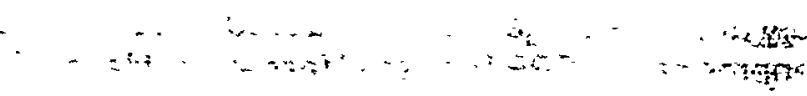

Note: Hood flows currently in use at TNX range from 55 to $65 \mathrm{scfm}$.

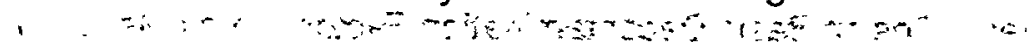

Note: The temperature of the cell air entering the hood, prior to mixing with the melter off-gas, for design calculations is assumed to be at $20^{\circ} \mathrm{C}$ although the actual temperature is more likely to be near $38^{\circ} \mathrm{C}\left(100^{\circ} \mathrm{F}\right)$. The lower temperature is assumed because a lower temperature results in a higher (more conservative) dry dilution air requirement due to the water evolved from the melter (even though the water content of. $100 \% \mathrm{RH}$ air at $20^{\circ} \mathrm{C}$ is less than that at $38^{\circ} \mathrm{C}$ ).

- Entrainment from Melter - $-<1: 0$ wt\% of calcine

Note: Preliminary results from off-gas sampling tests conducted by ORNL during process simulations conducted with the 3-inch CIM indicated no measurable entrainment. Off-gas sampling results for the 5 -inch CIM indicate less than 0.1 weight percent entrainment during the course of the entire run. Consequently, since the $1 \%$ entrainment assumption appears to be 
conservative based on the 3-inch and 5-inch CIM results, the material balance will not be changed at this time.

- Melter Exit Vapor Temperature - see Stream 61b, Material Balance

- Material of Construction - Design Authority to specify

- Position Relative to Top of Melter - shown above

- Dimensions of Hood - to be determined by Design to meet requirements

\section{Moisture Separator (Optional)}

\section{Design Bases}

There are two options available for the off-gas system.

The first is the use of a moisture separator (cyclone separator) before the HEPA filter. Dilution air would be added between the moisture separator and the HEPA. This is how the pilot system is currently setup. If a moisture separator is used, then it should remove any water droplets present that could impact the performance or integrity of the HEPA filter.

The second option is to move the dry dilution air piping immediately after the hood so that condensation cannot occur anywhere in the off-gas line. With this configuration, the moisture separator would not be needed. Also, with this configuration, the hood air flowrate could not be directly measured, but it can be calculated from the difference between the dry dilution air flowrate and the total flowrate exiting the HEPA filter; therefore, a flow measurement of the total flow exiting the HEPA filter is required:

Design is to evaluate the advantages and disadvantages of the two options and the Design Authority is responsible for selecting the preferred option.

\section{Dilution Air}

\section{Design Bases}

- The dilution air must have a dew point of no greater than $-20^{\circ} \mathrm{C}$.

- The required flowrate is that amount of dry air that will reduce the dew point of the resulting mixture of the hood exhaust and the dilution air to at least $10^{\circ} \mathrm{C}$ below the temperature of the off-gas entering the HEPA filter.

- Hood Flow - $100 \mathrm{scfm}$ for a cell air temperature entering the hood of $20^{\circ} \mathrm{C}$ and at a relative humidity of $100 \%$.

Note: The worst case for the dilution air is where most of the free water is evolved from the melter. The temperature of the off-gas exiting the melter during this stage is assumed to be $200^{\circ} \mathrm{C}$. 
Americium-Curium Stabilizátion - 5" Cylindrical

Induction Melter System Design Basis (U)
SRT-AMC-99-0001

: Revision 0

January 15, 1999

Page 46 of 52

When this off-gas is mixed with the hood (cell) air, a vapor stream that is above saturation at $21.35^{\circ} \mathrm{C}$ results. This stream is then diluted with the dry dilution air to give an off-gas at $20.45^{\circ} \mathrm{C}$ and a dew point of $10.37^{\circ} \mathrm{C}$.

For other melter off-gas temperatures or cell air temperatures, a material and energy balance must be performed to determine a new required dilution airflow.

High Efficiency Particulate Air (HEPA) Filter

\section{Design Bases}

- Dimensions - limit clean delta $P$ to 3.0 in w.c. at the total off-gas + dilution air flowrate (nominally $200 \mathrm{scfm}$ as calculated above)

- Particulate Removal Efficiency - use standard nuclear grade HEPA filters - nominally $99.97 \%$ removal for particles at 0.3 micron in diameter

\section{Exhauster}

\section{Design Bases}

Capable of maintaining the design basis centerline air velocity across the melter top at the total vessel vent flow.

\section{PROCESS CONTROLIDATA ACQUISITION SYSTEM}

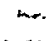

r.t.

The following is a process control/data acquisition system description for the pilot system at TNX [Ref. 11]. It is given for informational purposes only and is not intended to specify the system to be used in the MPPF.

A Modicon ${ }^{\otimes} 984$ Programmable Logic Controller (PLC) performs process control functions at the TNX pilot system. Operator interface functions are performed using a PC workstation. The workstation operates under Windows $N T^{\circledR}$ operating system, using a software package by US DATA Corporation (Factoryliñ ${ }^{\otimes}$ ) for operator interface to the process.

\section{General Requirements}

All control functions are performed via the Modicon, in that loss of communication between the Modicon and the workstation will not cause loss of control of the process. Resumption of communication will also not cause the loss or upset of control functions performed by the Modicon. All process set points are provided to the Modicon from the workstation. Initial values for interlock set points and controlled process equipment (i. e. valve positions etc.) are set to allow for safe process startup. 
Americium-Curium Stabilization - 5" Cylindrical

Induction Melter System Design Basis (U)

SRT-AMC-99-0001

: Revision 0

January 15, 1999

Page 47 of 52

Hardwired interlocks are provided to stop the process in the event of an emergency requiring shut down.

\section{Induction Power Controls}

Three heating zones are now available. These are defined as: the "melter or wall" zone which supplies heat to the vertical walls of the melter, the "cone" zone which supplies heat to the sloped bottom of the melter, and the "tip or drain tube" zone which supplies heat to the drain tube. Control of each of the zones is completely independent even though interaction between them is significant.

\section{Power Station Status}

The condition of each of the power stations is read using the RS-232 communication capability of the station. Data transmitted to the workstation includes: amps, volts, power, hertz, and status. The status message may be READY, HEATON, or FAULT.

\section{Melter Controls}

The power to the melter can be controllable in two modes: 1) manual control from the workstation and 2) temperature ramp control from the workstation.

\section{Mode 1}

In this mode, the power supplied to the melter is completely controlled by operator input at the workstation. Operator input is sent to the Modicon which sends the output to the power control cabinet.

\section{Mode 2}

In this mode, the power to the melter is incremented (up or down) once each minute by an amount specified by the operator to attain a temperature set point also supplied by the operator from the workstation. A subroutine running at the workstation is used to increment the output up or down. The.operator-also has the ability to select one of the five thermocouples of the melter upon which to compare the set point to the process reading. The operator also enters a cutoff temperature set point at the workstation. In the event any one of the five melter thermocouples exceeds this cutoff temperature set point, the output power is reduced by $0.5 \%$ once a minute until all temperatures are below the cutoff temperature. An alarm is also sounded to the alert the operator.

In the event of loss of communication between the workstation and the Modicon, the power output is frozen at the last value sent by the workstation. Restart of the work station results in the ramp function turned off, but the power output is at the value set prior to loss of communication. 


\section{Cone Power Control}

The cone power control has Modes 1 and 2 above and works identically to the melter controls. The operator selects one of the two thermocouples or an optical pyrometer in the cone section for Mode 2 control. Use of the optical pyrometer for Mode 2 control at temperatures below its range of $600^{\circ} \mathrm{C}$ is not possible.

\section{Pour Tip Power Control}

The pour tip power control has Modes 1 and 2 above and works identically to the melter controls. The operator selects one of the two thermocouples located on the drain tube or the optical pyrometer to control from.

\section{Recommended Alarms/lnterlocks}

Process alarms in the form of warnings are displayed on the workstation. These warnings indicate the approach to interlock conditions. Interlocks are also displayed at the workstation, but the Modicon performs interlock actions. The ability to disable individual interlocks from the workstation is also provided to allow for instrument calibrations and malfunctions.

\section{Data Collection}

All process data is collected each minute in a text file on the hard drive of the workstation. Process operations that require faster.collection rates (i. e. during pouring) àre collected using the report generator of Factorylink. Data cöllection for the pouring sequence is triggered by the start of the pouring sequence.

\section{Process Operations Logging}

All operator process actions, (i. e. Set point changes) are logged to the alarm printer with a time stamp and the new process setpoint.

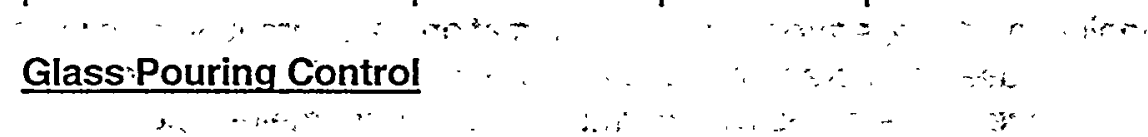

A program running on the workstation performs the pouring sequence and generates a report of pour parameters.. The. pouring sequence shuts off the holding air to the pour tip to start the pour: At the completion of the pour, the operator issues the stop pouring command at the workstation. The program then opens the top pour tip cooling air for a specified number of seconds. The lower tip holding air comes on a specified number of seconds after the top pour tip air has been on and remains on. Top pour tip air shuts off at the specified time. The report continues to run for a specified period after the completion of the pouring sequence. When completed the report file is automatically printed to the letter quality printer at the workstation. 
Americium-Curium Stabilization - 5" Cylindrical

Induction Melter System Design Basis (U)

SRT-AMC-99-0001

: Revision 0

January 15,1999

Page 49 of 52

$:$

\section{REFERENCES}

1. "Defense Nuclear Facilities Safety Board Recommendation 94-1 to the Secretary of Energy", May 26, 1994.

2. Memo from R. M. Bigler to A. Gunter, "Meeting Minutes - Am/Cm Stabilization (U)", October 4, 1994.

3. Memo from A. L. Schwallie to M. P. Fiori, Defense Nuclear Safety Board Recommendation 94-1, "Improved Schedule for Remediation in the Defense Nuclear Facilities Complex", WSR-94-0082, July 12, 1994.

4. J. E. Marra, "Am-Cm Stabilization Development Program Plan", SRT-AMC-980048, Rèv. 3, November 30, 1998.

5. M. E. Smith, et al., "Americium/Curium Preliminary Design Basis (U)," SRTAMC-98-0225, Rev. 0, September 30, 1998.

6. J. E. Marra, "Completion of 5" Cylindrical Induction Melter Demonstration Runs (U)," SRT-AMC-98-0300, December 10, 1998.

7. Rudisill, T. S., "Americium/Curium Extraction from a Lanthanide Borosilicate Glass (U)", SRT-CHT-97-0043, May 8, 1997.

8. Marek, J. C., "Hydrogen Generation from Am/Cm Vessels (U)," S-CLC-F00196, July 11, 1997.

Smith,-J. R., "Radiolysis Gases from Nitric Acid Solutions Containing HSA and HAN (U)", WSRC-TR-94-0525, October 28; 1994.

-.:- : i: :

9. "Am/Cm Disposition Packaging and Transportation Options and Evaluation, Final Draft", SRT-PTG-98-0094, July 28, 1998.

10. Marra, J. E., "R\&D Action Items 0.1.1 and 4.18 (U)", SRT-AMC-98-0228, September 18, 1998.

11. Baich, M. A., "Cylindrical Induction Melter (CIM) Control System Functional Basis", SRT-AMC-98-0017, Rev. 3, April 20, 1998. 
Americium-Curium Stabilizátion - 5" Cylindrical Induction Melter System Design Basis (U)

SRT-AMC-99-0001

: Revision 0

January 15, 1999

Page 50 of 52

\section{Laboratory Notebooks}

The following Laboratory Notebooks have been used throughout the experimental program to develop the batch process and equipment. These notebooks contain the raw data used to generate this report.

\section{Glass Formulation Studies}

$\begin{array}{ll}\text { WSRC-NB-96-616 } & \text { Am/Cm Batch Process - SrABS I } \\ \text { WSRC-NB-98-00141 } & \text { Am/Cm Batch Process - SrABS II } \\ \text { WSRC-NB-98-00200 } & \text { Am/Cm Batch.Process - SrABS III } \\ \text { WSRC-NB-98-00207 } & \text { Am/Cm Batch Process - SrABS IV } \\ \text { WSRC-NB-98-00208 } & \text { Am/Cm SrABS Variability Study } \\ & \end{array}$

\section{Precipitation/Process Equipment Dévelopment}

WSRC-NB-94-237

WSRC-NB-98-00233

WSRC-NB-98-00271

Drain Tube Test Stand

WSRC-NB-96-691

WSRC-NB-97-243

WSRC-NB-97-239

WSRC-NB-97-242

Cylindrical Indûction Melter

WSRC-NB- 97-246

WSRC-NB- 97-245

WSRC-NB- 98-00244
Am/Cm Feed Preparation

Coupled Precipitator

Coupled Precipitator One
Am/Cm Development - Drain Tube Test Stand Am/ Cm Development - Drain Tube Test Stand Am/Cm Development - Drain Tube Test Stand Am/Cm Development - Drain Tube Test Stand

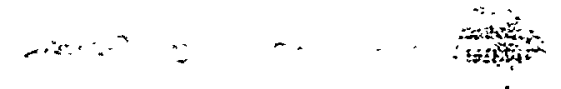

Am/Cm Cylindrical Induction Melter - No. 1 Am/Cm Cylindrical Induction Melter - No. 2 5" Cylindrical Induction Melter Development 
Americium-Curium Stabilization - 5" Cylindrical Induction Melter System Design Basis (U)

\section{Attachment 1 - Schematic Diagram of 5-Inch Cylindrical Induction Melter System}

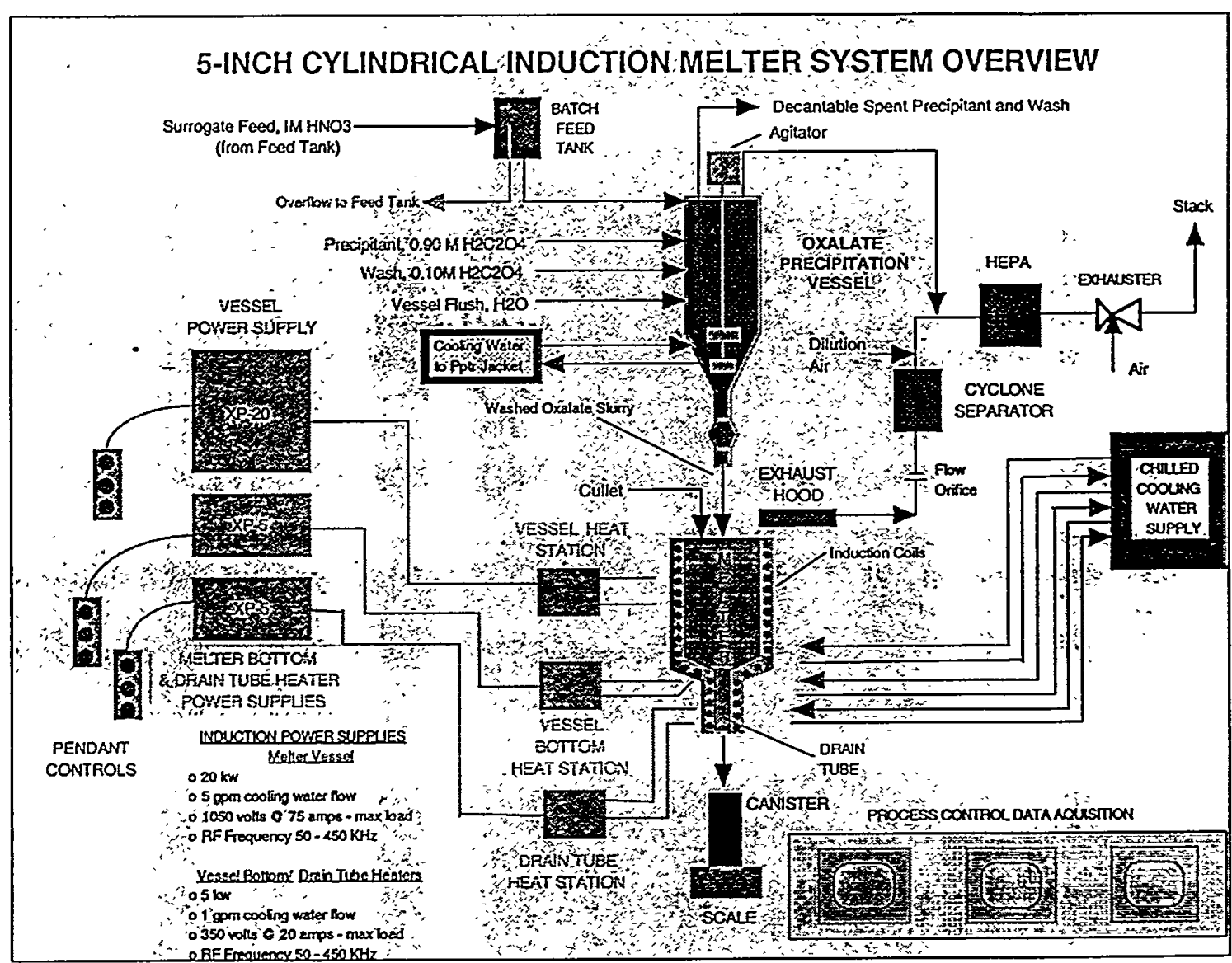


Americium-Curium Stabilizátion - 5" Cylindrical Induction Melter System Design Basis (U)
SRT-AMC-99-0001

: Revision 0

January 15, 1999

Page 52 of 52

\section{DISTRIBUTION}

Am-Cm Steering Team:

J.W. French, 703-F

G. W. Stanley, 730-B

G. T. Wright, 773-A

Am-Cm Technical Advisory Panel:

F. F. Cadek, 730-B

J. D. Cohen, 773-A

J. S. Evans, 703-F

L. M. Papouchado, 773-A

\section{Am-Cm Project Team:}

A. W. Bower, III, 704-10F

R. W. Williams, 704-10F

S. B. Speight, 704-10F

D. E. Grove, 730-1B

A. P. Giordano, $730-1 B$

N. H. Harkey, 730-1B

W. H. Martin, 704-T

M. E. Jerath, 704-T

Am-Cm Project Files (c/o Jean Rouse), 704-10F
Am-Cm Development Team:

M. J. Swain, 704-T

L. F. Landon, 704-1T

D. C. Witt, 704-1T

M. A. Baich, 704-T

A. P. Fellinger, 704-1T

B. J. Hardy, 773-42A

G. T. Jannik, 773-42A

T. M. Jones, 704-1T

C. B. Miller, 679-T

D. H. Miller, 704-1T

D. K. Peeler, 773-43A

T. K. Snyder, 704-T

M.E. Stone, 704-T

J. E Marra, 704-T (6)

SRTAME File $7041 \mathrm{~T}$ 